\title{
Abomasal protein infusion in postpartum transition dairy cows: Effect on performance and mammary metabolism
}

\author{
M. Larsen, ${ }^{* 1}$ H. Lapierre, $\dagger$ and N. B. Kristensen ${ }^{* 2}$ \\ *Department of Animal Science, Aarhus University, Foulum, DK-8830 Tjele, Denmark \\ †Dairy and Swine Research and Development Centre, Agriculture and Agri-Food Canada, Sherbrooke, Québec, J1M 0C8 Canada
}

\begin{abstract}
The effect of increasing the postpartum metabolizable protein (MP) supply on performance and mammary metabolism was studied using 8 Holstein cows in a complete randomized design. At parturition, cows were assigned to abomasal infusion of water (CTRL) or casein (CAS). Arterial and epigastric venous blood samples were taken $14 \mathrm{~d}$ before expected parturition and at 4, 15, and $29 \mathrm{~d}$ in milk (DIM). To compensate previously estimated deficiency of essential AA and to avoid oversupply, casein protein infusion was graduated with $696 \pm 1,490 \pm 9$, and $212 \pm 10 \mathrm{~g} / \mathrm{d}$ at 4 , 15 and 29 DIM, respectively. Dry matter intake was unaffected by CAS. Compared with CTRL, MP supply was greater at 4 DIM with CAS but did not differ by 29 DIM. Milk yield was greater with CAS $(+7.2 \pm$ $1.3 \mathrm{~kg} / \mathrm{d}$ from 1 to $29 \mathrm{DIM})$. Milk protein yield was greater with CAS at 4 DIM and averaged 1,664 \pm 39 $\mathrm{g} / \mathrm{d}$ compared with 1,212 $\pm 86 \mathrm{~g} / \mathrm{d}$ for CTRL, but did not differ at 29 DIM $(1,383 \pm 48 \mathrm{~g} / \mathrm{d})$. The ratio of MP total supply to requirement was numerically greater at 4 DIM for CAS compared with CTRL, indicating less postpartum protein deficiency. In contrast, a greater net energy deficiency tended to be induced with CAS, but the greater milk yield allowed a large part of mobilized fat to be secreted in milk. Arterial concentration of total essential AA increased sharply after parturition for CAS compared with slight decreases for CTRL. The patterns of arterial concentrations combined with arterial-mammary venous concentration differences indicated that Lys, Leu, and Tyr were the first-limiting $\mathrm{AA}$ at 4 DIM with CTRL. Mammary plasma flow was unaffected by treatment, indicating similar perfusion of mammary tissue. The greater milk yield with CAS was associated with greater mammary uptake of individual essential AA, tendencies to greater uptake of glucose, lactate, and $\beta$-hydroxybutyrate, whereas uptakes of
\end{abstract}

\footnotetext{
Received July 10, 2013.

Accepted May 11, 2014.

${ }^{1}$ Corresponding author: Mogens.Larsen@agrsci.dk

${ }^{2}$ Current address: Knowledge Centre for Agriculture, Agro Food Park 15, DK-8200 Aarhus N, Denmark.
}

volatile fatty acids were unaffected. Despite similar MP supply by 29 DIM, milk and lactose yields were greater with CAS indicating a persistent response to increased postpartum MP supply. In conclusion, the postpartum MP deficiency can have a substantial negative effect in dairy cows as the major outcome of increasing the postpartum MP supply was increased milk, milk protein, and lactose yield, as well as an enhanced MP balance. Potential positive effects for other body functions than milk synthesis are discussed. Future investigations are needed to delineate how to transfer the effect into practical feeding strategies.

Key words: dairy cow, protein, metabolism, periparturient

\section{INTRODUCTION}

The dilemma of the postpartum transition cow having to meet the rapid increase in nutrient requirements for milk synthesis by equivalent increments in nutrient intake has been formulated and emphasized repeatedly (Bell, 1995; Loor, 2010). The consequences of the negative energy balance and associated fat mobilization have received great focus during the past decades (Grummer, 1995; Ingvartsen et al., 2003; Loor, 2010). In contrast, the concomitant negative protein balance has received little attention, even though the extent and potential negative consequences have been acknowledged (Grummer, 1995; Bell et al., 2000).

The extent of postpartum negative protein balance was estimated to be greatest around $7 \mathrm{~d}$ postpartum, then diminishing and becoming positive during the fourth week postpartum (Bell et al., 2000). Recently, a similar pattern has been observed by relating the release of EAA from total splanchnic tissues to the secretion in milk (Larsen and Kristensen, 2009a; Dalbach et al., 2011). Consequently, during this period, AA are mobilized mainly from skeletal muscles (Gibb et al., 1992) and postpartum involution of smooth muscle in the uterus (Gibb et al., 1992; Andrew et al., 1994). The available protein seem to be partitioned mainly to protein synthesis over glucogenic purposes in the early postpartum period, as EAA did not contribute more to 
liver glucose release on a net basis in the postpartum period (Larsen and Kristensen, 2013).

The negative protein balance in the early postpartum period does further establish low blood concentrations of most EAA relative to the prepartum period (Doepel et al., 2002; Dalbach et al., 2011). The lowered circulating levels of EAA may compromise vital body functions, such as the immune defense system ( $\mathrm{Li}$ et al., 2007) and proliferation of splanchnic tissues (Gibb et al., 1992). With respect to the mammary gland, it has been observed that the mammary uptake of single EAA can be upregulated when protein supply was low for specific EAA (Bequette et al., 2000; Lapierre et al., 2009). Despite the metabolic flexibility of the mammary gland, it could be speculated that the general lowered circulating levels of EAA in the postpartum period are limiting mammary EAA uptake and milk protein synthesis.

The overall hypothesis of the present study was that the protein deficiency in the postpartum period limits animal performance; therefore, abomasal infusion of casein to postpartum transition cows will (1) increase blood EAA concentration, (2) increase mammary uptake of EAA, and (3) increase milk protein yield. The aim of the study was to investigate the effects of alleviating the protein deficiency in postpartum transition dairy cows on milk production, mammary metabolism, and mobilization of body reserves.

\section{MATERIALS AND METHODS}

The present experiment complied with Danish Ministry of Justice Law no. 382 (June 10, 1987), Act no. 726 (September 9, 1993), concerning experiments with animals and care of experimental animals.

\section{Animals, Diets, and Experimental Design}

Eight Holstein cows entering their second lactation were used in a complete randomized design with repeated measurements. Sampling days of blood were designated to prepartum $(-14.4 \pm 3.6 \mathrm{~d})$ and to 4.0 $\pm 0.0,14.9 \pm 0.8$, and $29.3 \pm 1.0$ DIM. At the day of parturition (designated as 1 DIM), cows were randomly assigned to 1 of 2 treatments: continuous abomasal infusion of water (CTRL) or casein (CAS). Abomasal infusion of casein protein (containing $91.0 \% \mathrm{CP}$ as fed) was planned to supply $360 \mathrm{~g} / \mathrm{d}$ at $1 \mathrm{DIM}, 720 \mathrm{~g} / \mathrm{d}$ at 2 DIM, followed by daily reductions of $19.5 \mathrm{~g} / \mathrm{d}$ ending at $194 \mathrm{~g} / \mathrm{d}$ at 29 DIM. The amount of casein infused was planned to supply the estimated deficient EAA at 4 and 29 DIM by Dalbach et al. (2011) and avoiding great oversupplies. The obtained casein protein infusion was initiated $6.0 \pm 1.7 \mathrm{~h}( \pm \mathrm{SD})$ after parturition and averaged $696 \pm 1,490 \pm 9$, and $212 \pm 10 \mathrm{~g} / \mathrm{d}$ at the 4, 15, and 29 DIM sampling days, respectively. An abomasal infusion device was placed in the abomasum via the ruminal cannula at the day of parturition, as previously described (Larsen and Kristensen, 2009b). The casein infusate was prepared daily as a $7.9 \%$ solution of Na-caseinate (Miprodan 30; Arla Foods Ingredients a.m.b.a., Viby, Denmark) using 50 to $55^{\circ} \mathrm{C}$ warm tap water and a mixer wagon for calf milk replacer. Infusates were infused using silicone tubing $(3 \mathrm{~mm}$ i.d., $6 \mathrm{~mm}$ o.d.; Ole Dich Instrumentmakers, Hvidovre, Denmark) and peristaltic pumps (Type 115/G42 with L-channels; Ole Dich Instrumentmakers).

All cows were offered the same prepartum and the same postpartum diets (Table 1) composed to fulfill the Nordic recommendation for nutrient allowances (Volden, 2011). The protein level in the basal postpartum diet was chosen to parallel feeding regimens using 1 TMR for all lactating cows. The prepartum feed intake was restricted to $10 \mathrm{~kg}$ of $\mathrm{DM} / \mathrm{d}$; postpartum, cows were fed ad libitum (10\% orts). Diets were offered as a TMR and fed in equally sized meals at 0830,1630 , and $0030 \mathrm{~h}$. Orts were weighed and removed at $0800 \mathrm{~h}$. Cows were milked at 0500, 1300, and $2100 \mathrm{~h}$.

Ruminal cannulas (\#1C; Bar Diamond, Parma, ID) were implanted 4 wk before dry off, and permanent indwelling catheters in the intercostal artery were implanted 4 to 6 wk before expected parturition, as previously described (Larsen and Kristensen, 2009b). On sampling days, a temporary catheter was placed in the right epigastric vein. Cows were dried off at 8 to 9 wk before expected parturition allowing at least $8 \mathrm{wk}$ of effective dry period. Cows were housed in tiestalls bedded with rubber mats and wood shavings and were moved to a straw-bedded calving pen at signs of parturition. The expulsed placenta was removed from the pen as soon as possible after parturition to prevent a protein boost from ingestion of the placenta.

\section{Experimental Sampling and Data Collection}

Feed intake and milk yield were recorded daily. Diets were sampled 2 times per week for DM determination, and the dried samples were pooled within diet and week for later chemical analyses. Milk yield was recorded using continuous flow sampling (TruTest HI, Tru-Test Scandinavia, Præst $\varnothing$, Denmark) and milk was sampled on blood sampling days at each milking from the continuous flow sample. Feces were sampled mornings and afternoons of the day before and at the 15 and 29 DIM sampling days. Fecal samples were pooled within cow and sampling day and stored at $-20^{\circ} \mathrm{C}$ until analysis. Cows were weighed before the afternoon feeding of each sampling day. 
Table 1. Composition of the total mixed diets fed pre- and postpartum

\begin{tabular}{|c|c|c|}
\hline $\begin{array}{l}\text { Item, } \mathrm{g} / \mathrm{kg} \text { of } \mathrm{DM} \\
\text { (unless otherwise noted) }\end{array}$ & Prepartum & Postpartum \\
\hline \multicolumn{3}{|l|}{ Ingredient } \\
\hline Corn silage & $450^{1}$ & $350^{2}$ \\
\hline Grass-clover silage $^{3}$ & 200 & 200 \\
\hline Barley straw, chopped & 120 & \\
\hline Wheat grain, ground & 90 & \\
\hline Wheat grain, $\mathrm{NaOH}$ treated & & 200 \\
\hline Soybean meal, $54 \%$ CP & 100 & 81 \\
\hline Rapeseed meal & & 81 \\
\hline Molasses, sugar cane & 13 & \\
\hline Sugar beet pulp, dried & & 60 \\
\hline Vegetable fat ${ }^{4}$ & 10 & 10 \\
\hline $\mathrm{CaCO}_{3}$ & & 5.2 \\
\hline $\mathrm{NaCl}$ & 5 & 1.3 \\
\hline Mineral-vitamin premix & $12^{5}$ & $7.5^{6}$ \\
\hline E-vitamin premix $^{7}$ & & 1.5 \\
\hline \multirow{2}{*}{\multicolumn{3}{|c|}{$\begin{array}{l}\text { I1(IV) } \mathrm{U}_{2} \\
\text { Nutrient }\end{array}$}} \\
\hline & & \\
\hline $\mathrm{DM}, \mathrm{g} / \mathrm{kg}$ & 425 & 522 \\
\hline Ash & 60 & 70 \\
\hline $\mathrm{CP}$ & 141 & 159 \\
\hline Starch & 202 & 236 \\
\hline $\mathrm{NDF}^{8}$ & 384 & 299 \\
\hline Metabolizable protein ${ }^{8}$ & 77 & 97 \\
\hline Metabolizable Lys, $\%$ of $\mathrm{MP}^{8}$ & 6.86 & 6.64 \\
\hline Metabolizable Met, $\%$ of $\mathrm{MP}^{8}$ & 2.22 & 2.20 \\
\hline $\mathrm{NE}_{\mathrm{L}}, \mathrm{MJ} / \mathrm{kg}$ of $\mathrm{DM}^{8}$ & 6.69 & 6.77 \\
\hline
\end{tabular}

${ }^{1}$ Chemical analysis: DM, 29.0\%; ash, $3.1 \%$ of DM; CP, $9.1 \%$ of DM; $\mathrm{NDF}, 40.2 \%$ of DM; starch, $30.9 \%$ of $\mathrm{DM}$; in vitro digestible $\mathrm{OM}$, $75.1 \%$ of DM.

${ }^{2}$ Chemical analysis: DM, 33.0\%; ash, $3.0 \%$ of DM; CP, $9.1 \%$ of DM; $\mathrm{NDF}, 38.2 \%$ of $\mathrm{DM}$; starch, $33.3 \%$ of $\mathrm{DM}$; in vitro digestible $\mathrm{OM}$, $76.6 \%$ of DM.

${ }^{3}$ Chemical analysis: DM, $47.1 \%$; ash, $8.8 \%$ of DM; CP, $13.6 \%$ of DM; NDF, $43.6 \%$ of DM; sugars, $8.4 \%$ of DM; in vitro digestible OM, $72.2 \%$ of DM.

${ }^{4}$ Palm fatty acid distillate (PFAD, Scanfedt A/S, Fredericia, Denmark). ${ }^{5}$ Premix dry (Gold D-alfa org. Se; Vitfoss, Gråsten, Denmark) containing (per kilogram): $20 \mathrm{~g}$ of Ca, $40 \mathrm{~g}$ of $\mathrm{P}, 192 \mathrm{~g}$ of $\mathrm{Mg}, 37 \mathrm{~g}$ of Na, 83 $\mathrm{g}$ of S, 1,091 kIU of vitamin A, $181.8 \mathrm{kIU}$ of vitamin D, 12,166 mg of RRR- $\alpha$-tocopherol, $5,455 \mathrm{mg}$ of $\mathrm{Mn}, 1,455 \mathrm{mg}$ of $\mathrm{Cu}, 35 \mathrm{mg}$ of $\mathrm{Co}$, 7,270 $\mathrm{mg}$ of $\mathrm{Zn}, 227 \mathrm{mg}$ of I, $18 \mathrm{mg}$ of Se, and $18 \mathrm{mg}$ of organic Se.

${ }^{6}$ Premix lactation (VM 2; Vitfoss) containing (per kilogram): $160 \mathrm{~g}$ of $\mathrm{Ca}, 5 \mathrm{~g}$ of $\mathrm{P}, 65 \mathrm{~g}$ of $\mathrm{Mg}, 90 \mathrm{~g}$ of $\mathrm{Na}, 2 \mathrm{~g}$ of $\mathrm{S}, 600 \mathrm{kIU}$ of vitamin A, $190 \mathrm{kIU}$ of vitamin D, 3,640 $\mathrm{mg}$ of $\alpha$-tocopherol, 4,000 $\mathrm{mg}$ of $\mathrm{Mn}, 1,500$ $\mathrm{mg}$ of $\mathrm{Cu}, 25 \mathrm{mg}$ of Co, 4,500 $\mathrm{mg}$ of Zn, $225 \mathrm{mg}$ of I, and $50 \mathrm{mg}$ of Se. ${ }^{7} \mathrm{E}$-vitamin premix (Suplex E-50000/K/selen; Vitfoss) containing (per kilogram): $172 \mathrm{~g}$ of Ca, $3 \mathrm{~g}$ of $\mathrm{P}, 45,500 \mathrm{mg}$ of $\alpha$-tocopherol, 2,300 $\mathrm{mg}$ of vitamin $\mathrm{K}_{3}, 1,766 \mathrm{mg}$ vitamin $\mathrm{B}_{3}$, and $100 \mathrm{mg}$ of Se.

${ }^{8}$ Calculated from ingredient analysis using the non-additive feed evaluation system NorFor (Volden, 2011).

On each sampling day, 4 bihourly sets of arterial and mammary venous blood were obtained starting $30 \mathrm{~min}$ before feeding at $0830 \mathrm{~h}$. Before collecting the main samples, whole blood samples were collected for immediate blood gas and oximetry measurements using heparinized 2-mL gas syringes (PICO50, Radiometer A/S, Copenhagen, Denmark). Main blood samples were collected using 10- or 20-mL disposable syringes and were immediately stabilized in either heparin
(\#455051; Greiner Bio-One GmbH, Kremsmünster, Austria) or $\mathrm{K}_{3}$ EDTA Vacuette tubes (\#455036; Greiner Bio-One $\mathrm{GmbH}$ ) and placed on crushed ice. Plasma was harvested by centrifugation at $3,000 \times g$ for $20 \mathrm{~min}$ at $4^{\circ} \mathrm{C}$ and stored at $-20^{\circ} \mathrm{C}$ until analysis.

\section{Analytical Procedures}

Feed samples were analyzed for DM, ash, CP, NDF, and starch as described by Kristensen et al. (2007). Dry matter and starch concentrations in feces were determined as described for feed samples. The $\mathrm{TiO}_{2}$ contents in the postpartum TMR and feces were determined according to (Myers et al., 2004). Milk samples were analyzed for fat, $\mathrm{CP}$, and lactose monohydrate by infrared spectrometry using a MilkoScan 4000 (Foss Electric, Hillerød, Denmark).

All analyses were performed on individual blood or plasma samples. Hematocrit was determined immediately after sampling in heparin-stabilized arterial samples by centrifugation in capillary tubes at 13,000 $\times g$ for 6 min at ambient temperature. Blood $\mathrm{pH}$, blood gasses, and oximetry variables were measured using an ABL700 Blood Gas Analyzer (Radiometer A/S, Copenhagen, Denmark). Heparinized plasma samples were analyzed for glucose and L-lactate using D-glucose oxidase and L-lactate oxidase, respectively (YSI 7100, YSI Inc., Yellow Springs, OH), and for BHBA, NEFA $\left(\mathrm{K}_{3}\right.$ EDTA plasma), and ammonia using a Cobas Mira autoanalyzer (Triolab A/S, Brøndby, Denmark) and enzymatic kits based on D-3-hydroxybutyrate dehydrogenase, acyl CoA synthetase/acyl CoA oxidase, and glutamate dehydrogenase, respectively (Ranbut 1008, FA 115, and AM 1015, respectively, Randox Laboratories Ltd., Crumlin, UK). Plasma insulin and IGF-1 were determined by time-resolved fluoroimmunometric assays according to Løvendahl and Purup (2002) and Frystyk et al. (1995), respectively. Intra- and interassay coefficients of variation were 3.3 and $3.0 \%$, respectively, for insulin, and 3.3 and $3.2 \%$, respectively, for IGF-1.

Heparinized plasma samples were analyzed for AA, 3-methyl-His (3MH), hydroxy-Pro (Hyp), and urea by GC-MS using the isotope dilution method (Calder et al., 1999). A working AA standard solution was prepared from a commercial AA mixture (AAS18, SigmaAldrich Denmark A/S, Brøndby, Denmark) with added Gln (L-Gln 99\%, final concentration $400 \mu M$, Acros, Geel, Belgium), 3MH (NT-methyl-L-histidine, final concentration $200 \mu M$, Sigma-Aldrich Denmark A/S), Hyp (hydroxy-L-proline, final concentration $200 \mu M$, SigmaAldrich Denmark A/S), and urea (final concentration 7,500 $\mu M$, Merck, Darmstadt, Germany). The internal standard was made from a $\left(\mathrm{U}_{-}{ }^{13} \mathrm{C} / \mathrm{U}_{-}{ }^{15} \mathrm{~N}\right)$ cell-free AA mixture (CNLM-6696-1; Cambridge Isotope Labora- 
tories Inc., Andover, MA) with added $\tau-\left[\mathrm{D}_{3}\right]$ methylL-His (DLM-2949; Cambridge Isotope Laboratories, Inc.), hydroxy-[2,5,5-D $]$ L-Pro (D-7186; CDN Isotopes, Pointe-Claire, Quebec, Canada), and $\left[{ }^{15} \mathrm{~N}_{2}\right]$ urea (no. 316830; Campro Scientific GmbH, Berlin, Germany). Ions used for detection of $3 \mathrm{MH}$, Hyp, and urea were 340,314 , and $231 \mathrm{~m} / \mathrm{z}$, respectively. Concentrations of VFA in heparinized plasma samples were determined by GC according to Kristensen (2000) coupled with a mass spectrometer as detector.

\section{Calculations and Statistical Procedures}

The MP supply from infused casein was calculated using a small intestinal digestibility of $94.6 \%$ (Chaudhry and Webster, 1993; Rutherfurd and Moughan, 1998). The utilization of $\mathrm{NE}_{\mathrm{L}}$ and $\mathrm{MP}$ was estimated as the ratio between total supply (including infused Na-caseinate) and requirement of $\mathrm{NE}_{\mathrm{L}}$ and $\mathrm{MP}$ calculated using the nonadditive Nordic feed evaluation system NorFor (Volden, 2011). The total-tract apparent digestibility of DM, CP, and starch was calculated for 15 and 29 DIM using $\mathrm{TiO}_{2}$ as an indigestible marker and average nutrient intake of the $2 \mathrm{~d}$ preceding the respective sampling day. Average milk composition was calculated taking differences in milk yield at morning, afternoon, and evening milkings into account. Energy-corrected milk yield was calculated taking lactose monohydrate concentration into account (Sjaunja et al., 1991). Each postpartum change in $\mathrm{BW}$ was calculated relative to the prepartum observation.

Whole blood concentrations of VFA were estimated from plasma concentrations by correcting for a $45 \%$ dilution space in erythrocytes (Kristensen, 2000). The ammonia concentration in whole blood was set equal to the plasma concentration, whereas the whole blood concentration of urea $\mathrm{N}$ was obtained by correcting for a urea dilution space in erythrocytes of $80 \%$ (Røjen et al., 2011). Mammary blood plasma flow was calculated using the Fick's principle with Phe and Tyr as markers, accounting for $3.37 \%$ blood-borne proteins and $5.0 \%$ NPN content in milk protein (Lapierre et al., 2012). Mammary whole blood flow was calculated by relating plasma flow to the simultaneous arterial hematocrit value. The mammary net flux of nutrients was calculated as the arterial-venous concentration difference multiplied by the appropriate mammary plasma or blood flow. The milk secretion of Phe and Tyr, as well as other AA, were calculated using an average AA composition of milk protein (Lapierre et al., 2012).

Data were subjected to ANOVA using the MIXED procedure in SAS (ver. 9.2, release TS1M0, SAS Institute Inc., Cary, NC). Postpartum observations were analyzed using a model including the fixed effects of treatment (Trt), DIM, sampling time relative to morning feeding and the possible interactions; DIM within cow and time relative to feeding within cow and DIM were considered as repeated measurements using compound symmetry and autoregressive order 1 covariance structures, respectively. For variables with 1 observation per day (daily or sampling days), a reduced model was used including Trt, DIM, and the Trt $\times$ DIM interaction; DIM within cow was considered as a repeated measure using the autoregressive order 1 covariance structure. The denominator degrees of freedom were calculated using the Kenward-Roger method. The LSM \pm SEM are presented as missing observations were present: udder edema prevented one epigastric sampling with CTRL at 4 DIM, and a mastitis incidence with CTRL at 4 DIM; thus, $\mathrm{n}=2$ for mammary data with CTRL at 4 DIM. Treatment means within DIM were separated using protected Fisher's least significant difference test. The prepartum observations were subsequently included to test the prepartum to 4 DIM difference $\times$ treatment interaction $\left(P_{\text {Trans } \times \text { trt }}\right)$ and for the general prepartum to 4 DIM difference $\left(P_{\text {Trans }}\right)$ using Fisher's least significant difference tests. Significance was declared at $P \leq 0.05$ and tendencies were considered at $0.05<P \leq 0.10$.

\section{RESULTS}

No calving problems and illnesses other than mastitis were observed (Table 2). Two incidences of mastitis were observed and cows responded quickly to veterinary treatment in both cases. One mastitis incidence was observed the evening before the 4 DIM sampling with a cow on CTRL; thus, mammary uptake of nutrients was not used for this observation.

\section{Feed Intake, Digestibility, Milk Production, and BW}

The voluntary DMI was not affected by treatment $(P$ $=0.35$; Figure 1a) and increased $(P<0.01)$ as lactation progressed with both treatments. Over the entire period, the profiled casein infusion gave higher and more constant postpartum MP supply with CAS com-

Table 2. Description of cows within treatment group $(\text { mean } \pm \mathrm{SD})^{1}$

\begin{tabular}{lcc}
\hline Item & CTRL & CAS \\
\hline BW at dry off, kg & $562 \pm 70$ & $581 \pm 50$ \\
BCS at dry off, $1-5$ scale & $2.9 \pm 0.1$ & $3.0 \pm 0.2$ \\
BW of born calves, kg & $40.5 \pm 3.5$ & $39.3 \pm 6.0$ \\
Twin births, no. & 0 & 0 \\
\hline
\end{tabular}

${ }^{1}$ Continuous abomasal infusion of water (CTRL) or Na-caseinate (CAS) from 1 to 29 DIM. 
pared with CTRL $(2.13 \pm 0.02$ vs. $1.81 \pm 0.05 \mathrm{~kg} / \mathrm{d}$; $P_{\text {Trt } \times \text { DIM }}=0.01 ;$ Figure $\left.1 \mathrm{~b}\right)$. The apparent total-tract digestibility of DM, CP, and starch were not affected by treatment $(P=0.25$ to $P=0.59$; Table 3$)$.

Through the experimental period, milk yield was constantly greater $(+7.2 \pm 1.3 \mathrm{~kg} / \mathrm{d} ; P<0.01$; Figure 1c) for CAS compared with CTRL, and increased as lactation progressed with both treatments $(P<0.01)$. Milk protein yield with CAS averaged 1,664 $\pm 39 \mathrm{~g} / \mathrm{d}$ at 4 DIM compared with $1,212 \pm 86 \mathrm{~g} / \mathrm{d}$ for CTRL, whereas milk protein yield did not differ at 29 DIM $\left(P_{\text {Trt }} \times\right.$ DIM $=0.03$; Table 3$)$. Milk protein concentration decreased more rapidly postpartum with CAS compared with CTRL $\left(P_{\text {Trt }} \times\right.$ DIM $\left.=0.05\right)$. Treatment neither affected absolute BW nor change in BW $(P=0.75$ and $P=0.78$, respectively; Table 3 ). The utilization of total $\mathrm{NE}_{\mathrm{L}}$ tended to be lower with CAS compared with CTRL $(P=0.08$; Table 3$)$, indicating a greater $\mathrm{NE}_{\mathrm{L}}$ deficiency with CAS. Numerically, the utilization of total MP increased faster postpartum for CTRL from below $100 \%$ compared with a slower increase for CAS from above $100 \%\left(P_{\text {Trt }} \times\right.$ DIM $\left.=0.11\right)$, indicating less postpartum protein deficiency with CAS.

\section{Arterial Concentrations}

The arterial concentrations of glucose, lactate, BHBA, insulin, and IGF-1 were not affected by treatment $(P=0.25$ to $P=0.71$; Table 4$)$. The arterial concentration of NEFA tended to increase more from prepartum to 4 DIM for CAS compared with CTRL $\left(P_{\text {Trans } \times \text { trt }}=0.07\right)$, but were not affected by treatment at 15 and 29 DIM $\left(P_{\text {Trt }} \times\right.$ DIM $\left.=0.06\right)$. The arterial concentrations of $3 \mathrm{MH}$ and Hyp increased sharply from prepartum to $4 \mathrm{DIM}(P<0.01)$, but were unaffected by treatment $\left(P_{\text {Trans } \times \text { trt }}=0.69\right.$ and $P_{\text {Trans } \times \text { trt }}=0.45$, respectively); postpartum, the concentration of $3 \mathrm{MH}$ remained unaffected by treatment $(P=0.92)$, whereas the concentration of Hyp tended $(P=0.08)$ to be lower for CAS compared with CTRL.

The arterial concentration of total EAA increased sharply after parturition for CAS compared with CTRL $\left(P_{\text {Trans }} \times\right.$ trt $\left.<0.01\right)$. Arterial concentrations of Ile, Leu, Lys, and Val either decreased or did not change from prepartum to 4 DIM for CTRL, but increased with CAS $\left(0.01 \leq P_{\text {Trans } \times \text { trt }} \leq 0.05\right.$; Table 4$)$. For His, Met, Phe, Thr, and Trp, no effect of treatment was observed on prepartum to 4 DIM difference $(P \geq 0.18)$. Postpartum, concentrations of Leu, Lys, and Val increased with CTRL as lactation progressed compared with steady or decreasing concentrations for CAS $\left(0.01 \leq P_{\text {Trt } \times \text { DIM }} \leq\right.$ $0.11)$. Arterial concentrations of His tended $(P=0.06)$ to be greater with CAS compared with CTRL. The concentration of Phe tended to be greater at 4 DIM

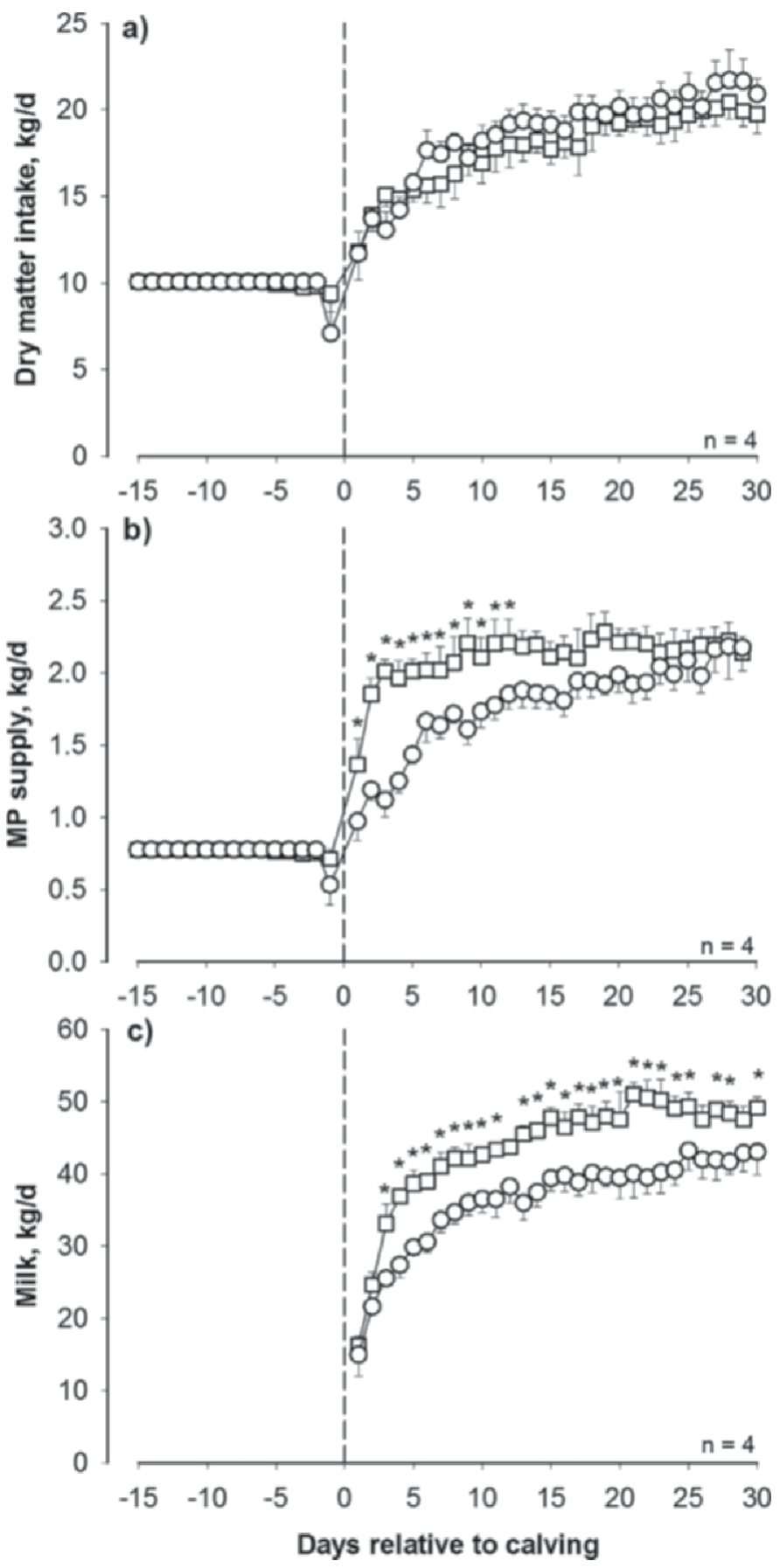

Figure 1. Voluntary DMI (a), metabolizable protein (MP) supply (b), and milk yield (c) in postpartum transition Holstein cows subjected to continuous abomasal infusion of either water ( $\mathrm{O}$; CTRL) or casein ( $\square$; CAS) initiated at the day of parturition. Each data point is the mean of 4 observations \pm SE. Asterisks $(*)$ signify treatment means to differ within DIM $(P \leq 0.05)$. The DMI was not affected by treatment $(P=0.35$; a) and increased $(P<0.01)$ as lactation progressed with both treatments. The profiling of casein infusion resulted in a high and more constant supply of MP from 2 to 29 DIM for CAS as compared with CTRL $\left(2.13 \pm 0.02\right.$ vs. $1.81 \pm 0.05 \mathrm{~kg} / \mathrm{d} ; P_{\text {treatment }} \times$ DIM $=0.01 ; \mathrm{b})$. Milk yield was greater $(+7.2 \pm 1.3 \mathrm{~kg} / \mathrm{d} ; P<0.01 ; \mathrm{c})$ with CAS compared with CTRL, and increased $(P<0.01)$ as lactation progressed with both treatments. 
Table 3. Intake, apparent total-tract digestibility, milk yield, milk composition, BW, and utilization of energy and protein $^{1}$

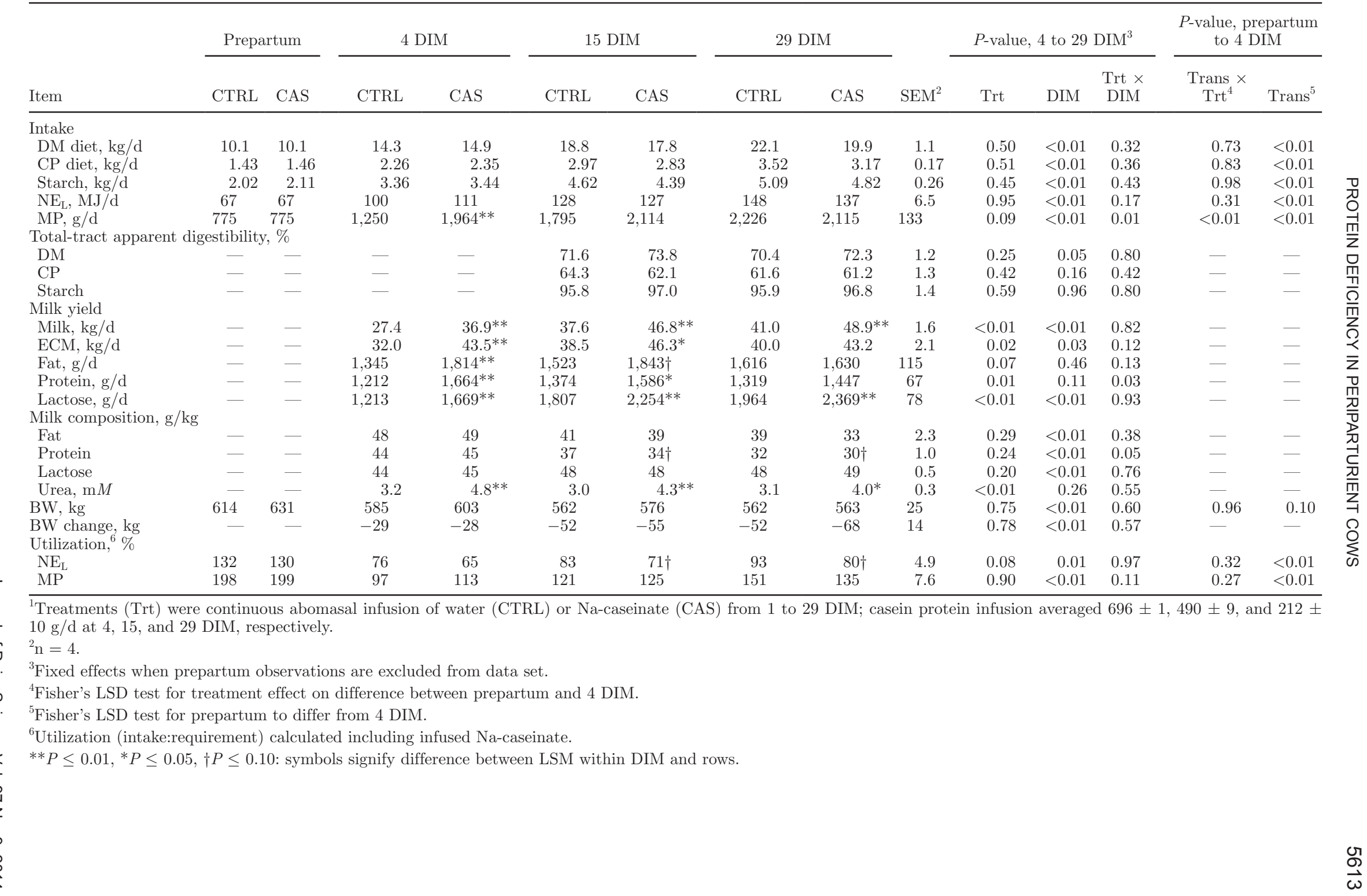


Table 4. Arterial variables ( $\mu M$ unless otherwise noted $)^{1}$

\begin{tabular}{|c|c|c|c|c|c|c|c|c|c|c|c|c|c|c|}
\hline \multirow[b]{2}{*}{ Item } & \multicolumn{2}{|c|}{ Prepartum } & \multicolumn{2}{|c|}{$4 \mathrm{DIM}$} & \multicolumn{2}{|c|}{15 DIM } & \multicolumn{2}{|c|}{29 DIM } & \multirow[b]{2}{*}{$\mathrm{SEM}^{2}$} & \multicolumn{3}{|c|}{$P$-value, 4 to $29 \mathrm{DIM}^{3}$} & \multicolumn{2}{|c|}{$P$-value, prepartum to $4 \mathrm{DIM}$} \\
\hline & CTRL & CAS & CTRL & CAS & CTRL & CAS & CTRL & CAS & & Trt & DIM & $\begin{array}{c}\text { Trt } \times \\
\text { DIM }\end{array}$ & $\underset{\operatorname{Trt}^{4}}{\operatorname{Trans}} \times$ & Trans $^{5}$ \\
\hline \multicolumn{15}{|l|}{ Blood plasma } \\
\hline Glucose, $\mathrm{m} M$ & 3.57 & 3.72 & 3.07 & 2.97 & 3.07 & 2.99 & 3.31 & 3.13 & 0.17 & 0.54 & 0.23 & 0.92 & 0.33 & $<0.01$ \\
\hline L-Lactate, $\mathrm{m} M$ & 0.53 & 0.50 & 0.48 & 0.35 & 0.28 & 0.24 & 0.28 & 0.26 & 0.05 & 0.25 & 0.01 & 0.45 & 0.23 & 0.03 \\
\hline NEFA & 154 & 173 & 376 & $572^{* *}$ & 306 & 321 & 153 & 166 & 45 & 0.12 & $<0.01$ & 0.06 & 0.07 & $<0.01$ \\
\hline BHBA & 791 & 723 & 742 & 1,344 & 731 & 1,202 & 669 & 1,168 & 379 & 0.28 & 0.89 & 0.97 & 0.22 & 0.29 \\
\hline Insulin, $\mathrm{p} M$ & 62 & 53 & 10 & 16 & 21 & 18 & 22 & 27 & 5.9 & 0.71 & 0.01 & 0.36 & 0.08 & $<0.01$ \\
\hline IGF-1, ng/mL & 173 & 187 & 48 & 59 & 70 & 90 & 73 & 84 & 11 & 0.36 & $<0.01$ & 0.79 & 0.90 & $<0.01$ \\
\hline 3-Methyl-His & 6.2 & 7.0 & 14 & 14 & 5.2 & 5.2 & 3.7 & 3.7 & 1.0 & 0.92 & $<0.01$ & 0.99 & 0.69 & $<0.01$ \\
\hline Hydroxy-Pro & 14 & 14 & 21 & 18 & 15 & 13 & 14 & 12 & 1.2 & 0.08 & $<0.01$ & 0.90 & 0.45 & $<0.01$ \\
\hline EAA & 630 & 674 & 583 & $1,026^{* *}$ & 833 & 985 & 772 & 900 & 96 & 0.08 & 0.27 & 0.04 & $<0.01$ & 0.02 \\
\hline His & 48 & 61 & 48 & 58 & 46 & 54 & 45 & 55 & 4.1 & 0.06 & 0.62 & 0.97 & 0.68 & 0.60 \\
\hline Ile & 91 & 104 & 92 & 175 & 121 & 154 & 107 & 143 & 27 & 0.20 & 0.68 & 0.19 & 0.05 & 0.05 \\
\hline Leu & 93 & 98 & 75 & $183^{* *}$ & 115 & 158 & 98 & 129 & 24 & 0.08 & 0.38 & 0.07 & 0.01 & 0.06 \\
\hline Lys & 65 & 64 & 49 & $82^{* *}$ & 72 & 77 & 70 & 78 & 5.4 & 0.06 & 0.01 & $<0.01$ & $<0.01$ & 0.72 \\
\hline Met & 19 & 22 & 21 & 24 & 23 & 21 & 23 & 22 & 1.8 & 0.91 & 0.92 & 0.19 & 0.79 & 0.16 \\
\hline Phe & 44 & 45 & 43 & 50 & 51 & 50 & 46 & 48 & 3.6 & 0.63 & 0.07 & 0.09 & 0.18 & 0.38 \\
\hline Thr & 76 & 82 & 78 & 93 & 116 & 102 & 132 & 121 & 17 & 0.86 & 0.01 & 0.41 & 0.69 & 0.54 \\
\hline Trp & 32 & 29 & 28 & 30 & 43 & 39 & 41 & 41 & 1.8 & 0.70 & $<0.01$ & 0.10 & 0.21 & 0.41 \\
\hline Val & 161 & 168 & 151 & $332^{* *}$ & 246 & 314 & 209 & 264 & 44 & 0.09 & 0.32 & 0.11 & 0.01 & 0.02 \\
\hline NEAA & 1,070 & 1,195 & 1,233 & 1,328 & 1,371 & 1,443 & 1,292 & 1,272 & 66 & 0.53 & 0.04 & 0.50 & 0.75 & $<0.01$ \\
\hline Ala & 184 & 171 & 178 & 143 & 214 & 184 & 234 & 199 & 21 & 0.24 & $<0.01$ & 0.98 & 0.42 & 0.22 \\
\hline Asn & 32 & 38 & 35 & 43 & 52 & 52 & 54 & 55 & 2.3 & 0.35 & $<0.01$ & 0.10 & 0.65 & 0.04 \\
\hline Asp & 3.9 & 4.0 & 2.3 & 3.0 & 3.2 & 3.4 & 3.1 & 3.7 & 0.6 & 0.55 & 0.02 & 0.63 & 0.35 & $<0.01$ \\
\hline Cys & 111 & 98 & 82 & 95 & 120 & 109 & 125 & 109 & 7.5 & 0.68 & $<0.01$ & $<0.01$ & $<0.01$ & $<0.01$ \\
\hline Gln & 292 & 381 & 202 & 248 & 183 & 239 & 184 & 228 & 20 & 0.10 & 0.17 & 0.81 & 0.23 & $<0.01$ \\
\hline Glu & 69 & 68 & 41 & 40 & 46 & 43 & 41 & 43 & 4.0 & 0.91 & 0.16 & 0.43 & 0.96 & $<0.01$ \\
\hline Gly & 208 & 253 & 476 & 480 & 486 & 514 & 413 & 393 & 32 & 0.91 & 0.01 & 0.66 & 0.40 & $<0.01$ \\
\hline Pro & 60 & 60 & 63 & $127^{* *}$ & 89 & $122^{* *}$ & 89 & 98 & 5.7 & $<0.01$ & 0.03 & $<0.01$ & $<0.01$ & $<0.01$ \\
\hline Ser & 69 & 82 & 127 & 102 & 130 & 114 & 106 & 96 & 16 & 0.32 & 0.33 & 0.85 & 0.15 & 0.01 \\
\hline Tyr & 41 & 42 & 29 & $46^{* *}$ & 47 & 47 & 43 & 43 & 3.8 & 0.24 & 0.01 & 0.01 & $<0.01$ & 0.27 \\
\hline Total AA & 1,700 & 1,878 & 1,818 & $2,355^{* *}$ & 2,204 & 2,424 & 2,064 & 2,173 & 99 & 0.07 & $<0.01$ & $<0.01$ & $<0.01$ & $<0.01$ \\
\hline \multicolumn{15}{|l|}{ Whole blood } \\
\hline Hematocrit, \% & 28.7 & 29.9 & 31.6 & 31.3 & 28.3 & 28.0 & 27.1 & 26.1 & 0.66 & 0.56 & $<0.01$ & 0.29 & 0.03 & $<0.01$ \\
\hline $\mathrm{pH}$ & 7.45 & 7.45 & 7.45 & 7.45 & 7.42 & 7.43 & 7.44 & 7.43 & 0.01 & 0.91 & 0.04 & 0.40 & 0.57 & 0.83 \\
\hline $\mathrm{O}_{2}, \mathrm{~m} M$ & 6.0 & 6.4 & 6.6 & 6.7 & 5.9 & 6.1 & 5.7 & 5.7 & 0.14 & 0.61 & $<0.01$ & 0.07 & 0.05 & $<0.01$ \\
\hline $\mathrm{CO}_{2}, \mathrm{~m} M$ & 24.2 & 23.5 & 27.1 & 26.2 & 26.5 & 25.8 & 26.3 & 26.2 & 0.67 & 0.52 & 0.52 & 0.66 & 0.88 & $<0.01$ \\
\hline Ammonia & 91 & 86 & 91 & 81 & 82 & 78 & 77 & 72 & 5.7 & 0.43 & $<0.01$ & 0.38 & 0.52 & 0.46 \\
\hline Urea, $\mathrm{m} M$ & 3.7 & 3.6 & 3.3 & $4.7^{* *}$ & 3.1 & $4.2^{*}$ & 3.3 & 4.0 & 0.3 & 0.01 & 0.37 & 0.49 & 0.01 & 0.21 \\
\hline Acetate & 1,564 & 1,364 & 1,288 & 1,382 & 1,569 & 1,662 & 1,633 & 1,786 & 164 & 0.62 & $<0.01$ & 0.86 & 0.07 & 0.10 \\
\hline Propionate & 25 & 17 & 41 & 39 & 59 & 52 & 48 & 52 & 6.1 & 0.83 & 0.01 & 0.44 & 0.44 & $<0.01$ \\
\hline Butyrate & 18 & 14 & 32 & 33 & 50 & 42 & 35 & $44 \dagger$ & 3.6 & 0.86 & $<0.01$ & 0.02 & 0.38 & $<0.01$ \\
\hline Isobutyrate & 3.1 & 2.1 & 4.6 & 4.1 & 5.4 & 4.0 & 4.7 & 4.6 & 1.2 & 0.67 & 0.82 & 0.50 & 0.61 & $<0.01$ \\
\hline Valerate & 0.4 & 0.4 & 0.7 & 0.7 & 1.0 & 0.6 & 1.0 & 0.5 & 0.3 & 0.41 & 0.93 & 0.44 & 0.89 & 0.17 \\
\hline Isovalerate & 3.7 & 2.8 & 4.3 & 4.2 & 5.1 & 4.4 & 4.5 & 4.8 & 0.5 & 0.77 & 0.20 & 0.25 & 0.13 & $<0.01$ \\
\hline Caproate & 0.5 & 0.3 & 0.3 & 1.0 & 0.3 & 1.3 & 0.8 & 1.4 & 0.3 & 0.11 & 0.13 & 0.66 & 0.05 & 0.18 \\
\hline
\end{tabular}

${ }^{1}$ Treatments (Trt) were continuous abomasal infusion of water (CTRL) or Na-caseinate (CAS) from 1 to 29 DIM; casein protein infusion averaged $696 \pm 1,490 \pm 9$, and $212 \pm 10 \mathrm{~g} / \mathrm{d}$ at 4,15, and 29 DIM, respectively.

${ }^{2} \mathrm{n}=4$.

${ }^{3}$ Fixed effects when prepartum observations are excluded from data set.

${ }^{4}$ Fisher's LSD test for treatment effect on difference between prepartum and 4 DIM.

${ }_{* *} P \leq 0.01, * P \leq 0.05, \dagger P \leq 0.10$ : symbols signify difference between LSM within DIM and rows. 
for CAS compared with CTRL and did not differ at 29 DIM $\left(P_{\text {Trt }} \times\right.$ DIM $\left.=0.09\right)$. Arterial concentrations of Met and Thr were generally unaffected by treatment $(P \geq$ $0.86)$. Overall, concentrations of total nonessential AA were not affected by treatment $(P=0.50)$ but increased with DIM $(P=0.05)$. Individually, arterial concentrations of Cys, Pro, and Tyr either decreased or did not change from prepartum to 4 DIM for CTRL compared with increased concentrations with CAS $\left(P_{\text {Trans } \times \text { trt }}<\right.$ 0.01; Table 4); postpartum, concentrations increased with CTRL as lactation progressed compared with steady or decreasing levels for CAS $\left(P_{\text {Trt } \times \text { DIM }} \leq 0.01\right)$.

The arterial concentrations of urea increased more from prepartum to 4 DIM for CAS compared with CTRL $\left(P_{\text {Trans }} \times\right.$ trt $\left.=0.01\right)$; postpartum, arterial urea concentrations were greater for CAS compared with CTRL $(P=0.01)$. Concentrations of acetate and propionate in arterial plasma were unaffected by treatment $(0.62 \leq P \leq 0.83$; Table 4) and increased as lactation progressed $(P \leq 0.01)$. The arterial concentration of butyrate was greater at 29 DIM for CAS, whereas concentrations did not differ at 4 and 15 DIM $\left(P_{\text {Trt }} \times\right.$ DIM $=0.02)$.

\section{Mammary Arterial-Venous Concentration Differences}

The mammary arterial-venous (A-V) concentration difference of glucose tended to increase more from prepartum to 4 DIM with CAS compared with CTRL $\left(P_{\text {Trans } \times \text { trt }}=0.08\right.$; Table 5$)$. Postpartum, the mammary A-V concentration difference of glucose was unaffected $(P=0.47)$ by treatment, but increased with progressing lactation $(P<0.01)$. For lactate, the mammary $\mathrm{A}-\mathrm{V}$ concentration difference was negative prepartum, indicating a net release of lactate by the mammary gland. The mammary A-V concentration difference of lactate increased from negative for CTRL and from zero for CAS at 4 DIM to positive and not differing between treatments at $29 \mathrm{DIM}\left(P_{\mathrm{Trt}} \times \mathrm{DIM}=0.01\right)$. The mammary $\mathrm{A}-\mathrm{V}$ concentration difference of BHBA tended to be greater with CAS compared with CTRL $(P=$ $0.09)$ and increasing with DIM for both treatments $(P$ $<0.01)$.

The mammary A-V concentration differences of Leu, Lys, and Tyr increased more from prepartum to 4 DIM for CAS compared with CTRL (0.01 $\leq$ $P_{\text {Trans } \times \text { trt }} \leq 0.09$; Table 5$)$. The increase in mammary A-V concentration differences of His, Ile, Met, Phe, Thr, Trp, and Val from prepartum to 4 DIM were unaffected by treatment $\left(0.14 \leq P_{\text {Trans } \times \text { trt }} \leq 0.82\right)$. Postpartum, mammary A-V concentration differences of EAA other than His and Val were greater at 4 DIM for CAS compared with CTRL, but did not differ by 29 DIM (0.01 $\leq P_{\text {Trt }} \times$ DIM $\leq 0.12$ ). The mammary $\mathrm{A}-\mathrm{V}$ concentration difference of His tended to be greater for CAS $\left(P_{\text {Trt }}=\right.$ 0.10) compared with CTRL, whereas mammary A-V concentration difference of Val was unaffected by treatment $\left(P_{\text {Trt }}=0.25\right)$, yet increasing with the progressing lactation $\left(P_{\mathrm{DIM}}<0.01\right)$. For the nonessential AA, mammary A-V concentration differences of Asn, Cys, Pro, and Tyr were greater at 4 DIM for CAS compared with CTRL, but did not differ by 29 DIM $\left(P_{\text {Trt } \times \text { DIM }} \leq 0.03\right)$.

The mammary A-V concentration differences of acetate, propionate, and butyrate were unaffected by initiation of lactation $\left(0.13 \leq P_{\text {Trans }} \leq 0.73\right.$; Table 5$)$. Postpartum, mammary A-V concentration differences of acetate, propionate, and butyrate were unaffected by treatment $\left(P_{\operatorname{Trt}} \geq 0.63\right)$, but increased with the progressing lactation for both treatments $\left(0.01 \leq P_{\mathrm{DIM}} \leq\right.$ $0.07)$.

\section{Net Mammary Uptake of Nutrients}

The absolute mammary plasma flow was not affected by CAS infusion or DIM ( $P \geq 0.24$; Table 6$)$, but when expressed relative to milk yield it was greater with CTRL at 4 DIM compared with CAS and did not differ between treatments by 29 DIM $\left(P_{\text {Trt }} \times\right.$ DIM $\left.=0.11\right)$. The mammary net uptake of glucose and BHBA tended to be greater for CAS compared with CTRL from 4 through to 29 DIM $(P=0.10$ and $P=0.08$, respectively). A net release of lactate (negative net flux) by the mammary gland was observed at 4 DIM for CTRL compared with a net uptake for CAS, but by 29 DIM; net lactate uptake was observed with both treatments $\left(P_{\text {Trt }} \times\right.$ DIM $\left.=0.06\right)$.

Mammary uptake of total EAA was greater for CAS compared with CTRL $(P<0.01)$ and increased with increasing DIM $(P=0.01$; Table 6$)$. Mammary uptake of each individual EAA was or tended to be greater for CAS compared with CTRL $(0.01<P \leq 0.11)$. Mammary uptake of total nonessential AA tended to increase $(P=0.06)$ with CAS infusion and decreased $(P=0.01)$ with DIM. The mammary uptake of acetate, propionate, and butyrate were unaffected by treatment $(0.44 \leq P \leq 0.90)$. Mammary uptake of $\mathrm{O}_{2}$ and release of $\mathrm{CO}_{2}$ were numerically larger $(P \leq 0.18)$ for CAS than for CTRL.

The mammary net uptake-to-milk output ratio (U:O) of His increased numerically to be above unity as lactation progressed for CAS as compared with $\mathrm{U}: \mathrm{O}$ ratios not different from unity for CTRL $\left(P_{\text {Trt }} \times\right.$ DIM $=0.13$; Table 7 ). For Met and Trp, the U:O ratios were not different from unity and were unaffected by treatment $(P=0.72$ and $P=0.71$, respectively). The $\mathrm{U}: \mathrm{O}$ ratio for Lys was greater for CAS compared with CTRL $(P=0.01)$ and increased numerically with the progressing lactation for both treatments $(P=0.14)$ 


\begin{tabular}{|c|c|c|c|c|c|c|c|c|c|c|c|c|c|c|}
\hline \multirow[b]{2}{*}{ Item } & \multicolumn{2}{|c|}{ Prepartum } & \multicolumn{2}{|c|}{$4 \mathrm{DIM}$} & \multicolumn{2}{|c|}{15 DIM } & \multicolumn{2}{|c|}{29 DIM } & \multirow[b]{2}{*}{$\mathrm{SEM}^{2}$} & \multicolumn{3}{|c|}{$P$-value: 4 to $29 \mathrm{DIM}^{3}$} & \multicolumn{2}{|c|}{$\begin{array}{l}P \text {-value: pre } \\
\text { to } 4 \text { DIM }\end{array}$} \\
\hline & CTRL & CAS & CTRL & CAS & CTRL & CAS & CTRL & CAS & & Trt & DIM & $\begin{array}{l}\text { Trt } \times \\
\text { DIM }\end{array}$ & $\underset{\operatorname{Trt}^{4}}{\operatorname{Trans}} \times$ & Trans $^{5}$ \\
\hline \multicolumn{15}{|l|}{ Blood plasma } \\
\hline Glucose, $\mathrm{m} M$ & 0.18 & 0.18 & 0.49 & 0.66 & 0.82 & 0.86 & 0.90 & 0.90 & 0.06 & 0.47 & $<0.01$ & 0.29 & 0.08 & $<0.01$ \\
\hline L-Lactate, $\mathrm{m} M$ & -0.07 & -0.09 & -0.07 & $0.03^{* *}$ & 0.04 & 0.04 & 0.07 & 0.06 & 0.02 & 0.44 & $<0.01$ & 0.01 & 0.12 & 0.13 \\
\hline BHBA & 135 & 122 & 149 & $244 \dagger$ & 305 & 374 & 328 & 385 & 30 & 0.09 & $<0.01$ & 0.64 & 0.09 & 0.03 \\
\hline EAA & 47 & 70 & 209 & $269^{*}$ & 274 & 303 & 267 & 290 & 15 & 0.07 & 0.01 & 0.26 & 0.19 & $<0.01$ \\
\hline His & 3.7 & 3.9 & 11 & 12 & 12 & 15 & 12 & $16 \dagger$ & 1.4 & 0.10 & 0.21 & 0.92 & 0.82 & $<0.01$ \\
\hline Ile & 6.9 & 12 & 30 & $39^{*}$ & 40 & 43 & 41 & 40 & 2.4 & 0.30 & 0.01 & 0.04 & 0.31 & $<0.01$ \\
\hline Leu & 11 & 15 & 44 & 58 & 57 & 62 & 57 & 57 & 3.6 & 0.21 & 0.09 & 0.11 & 0.09 & $<0.01$ \\
\hline Lys & 13 & 16 & 34 & $50^{* *}$ & 48 & 52 & 46 & 51 & 2.3 & 0.03 & 0.01 & 0.01 & $<0.01$ & $<0.01$ \\
\hline Met & 2.6 & 3.6 & 10 & $13 \dagger$ & 13 & 13 & 13 & 13 & 1.0 & 0.65 & 0.47 & 0.07 & 0.14 & $<0.01$ \\
\hline Phe & 2.1 & 3.3 & 17 & $21 \dagger$ & 22 & 22 & 21 & 21 & 1.3 & 0.48 & 0.24 & 0.12 & 0.17 & $<0.01$ \\
\hline Thr & 2.7 & 4.4 & 22 & $29^{*}$ & 29 & 27 & 27 & 26 & 1.6 & 0.60 & 0.41 & 0.07 & 0.20 & $<0.01$ \\
\hline $\operatorname{Trp}$ & 0.6 & 0.7 & 3.9 & 5.3 & 5.0 & 5.0 & 5.5 & 5.2 & 0.4 & 0.46 & 0.42 & 0.12 & 0.38 & $<0.01$ \\
\hline Val & 5.0 & 10 & 34 & 44 & 49 & 55 & 49 & 49 & 3.2 & 0.25 & $<0.01$ & 0.22 & 0.54 & $<0.01$ \\
\hline NEAA & 27 & 55 & 188 & 242 & 217 & 234 & 203 & 233 & 18 & 0.15 & 0.77 & 0.36 & 0.59 & $<0.01$ \\
\hline Ala & 0.5 & 2.3 & 41 & 37 & 41 & 37 & 42 & 41 & 3.0 & 0.37 & 0.63 & 0.87 & 0.36 & $<0.01$ \\
\hline Asn & 2.3 & 5.5 & 13 & $18^{*}$ & 19 & 17 & 19 & 17 & 1.2 & 0.84 & 0.35 & 0.01 & 0.64 & $<0.01$ \\
\hline Asp & 1.2 & 1.2 & 2.2 & 2.1 & 2.6 & 2.4 & 2.6 & 2.7 & 0.3 & 0.89 & 0.02 & 0.57 & 0.84 & 0.01 \\
\hline Cys & 1.2 & 3.5 & -0.2 & $4.8^{*}$ & 5.6 & 4.4 & 4.7 & 3.5 & 1.2 & 0.78 & 0.28 & 0.03 & 0.32 & 0.95 \\
\hline Gln & 32 & 38 & 49 & 76 & 51 & 59 & 42 & 54 & 11 & 0.31 & 0.06 & 0.26 & 0.51 & 0.22 \\
\hline Glu & 19 & 23 & 24 & 26 & 30 & 27 & 27 & 28 & 2.8 & 0.82 & 0.20 & 0.22 & 0.76 & 0.07 \\
\hline Gly & -27 & -18 & 3.2 & 6.7 & 4.5 & 7.4 & 7.5 & 7.6 & 3.3 & 0.65 & 0.57 & 0.73 & 0.67 & $<0.01$ \\
\hline Pro & -0.6 & 0.2 & 18 & $31^{* *}$ & 17 & $25^{* *}$ & 17 & 20 & 1.7 & 0.01 & $<0.01$ & 0.01 & $<0.01$ & $<0.01$ \\
\hline Ser & -3.0 & -4.8 & 18 & 28 & 21 & 24 & 25 & 27 & 2.8 & 0.28 & 0.29 & 0.19 & 0.07 & $<0.01$ \\
\hline Tyr & 2.4 & 4.0 & 15 & $21^{* *}$ & 20 & 21 & 21 & 21 & 1.2 & 0.24 & 0.31 & 0.03 & 0.07 & $<0.01$ \\
\hline \multirow{2}{*}{\multicolumn{15}{|c|}{ Whole blood }} \\
\hline & & & & & & & & & & & & & & \\
\hline $\mathrm{O}_{2}, \mathrm{~m} M$ & 2.0 & 1.8 & 1.4 & 1.5 & 1.6 & 1.7 & 1.8 & 1.8 & 0.1 & 0.64 & $<0.01$ & 0.44 & 0.23 & $<0.01$ \\
\hline $\mathrm{CO}_{2}, \mathrm{~m} M$ & -2.1 & -2.4 & -1.8 & -1.9 & -2.0 & -2.2 & -2.5 & -2.2 & 0.2 & 0.97 & 0.11 & 0.41 & 0.70 & 0.07 \\
\hline Ammonia & -1.5 & -0.2 & -0.6 & 2.1 & 6.6 & 8.8 & 8.8 & 10 & 1.5 & 0.12 & $<0.01$ & 0.91 & 0.69 & 0.36 \\
\hline Urea & 13 & 95 & -15 & -34 & -33 & -37 & -13 & -8 & 14 & 0.68 & 0.16 & 0.64 & 0.08 & 0.01 \\
\hline Acetate & 666 & 728 & 668 & 739 & 1,043 & 980 & 1,119 & 1,146 & 61 & 0.99 & $<0.01$ & 0.26 & 0.93 & 0.73 \\
\hline Propionate & 13 & 12 & 15 & 20 & 30 & 23 & 20 & 21 & 3.7 & 0.64 & 0.07 & 0.25 & 0.41 & 0.13 \\
\hline Butyrate & 8.3 & 6.8 & 3.1 & 7.4 & 11.8 & 10.1 & 9.7 & 11.1 & 2.0 & 0.63 & 0.03 & 0.29 & 0.12 & 0.22 \\
\hline Isobutyrate & 0.6 & 0.3 & 0.4 & -0.6 & -0.4 & -0.1 & -0.6 & -0.4 & 0.4 & 0.85 & 0.68 & 0.25 & 0.38 & 0.17 \\
\hline Valerate & -0.3 & -0.04 & -0.3 & 0.3 & 0.4 & 0.1 & 0.6 & -0.1 & 0.3 & 0.40 & 0.91 & 0.10 & 0.47 & 0.60 \\
\hline Isovalerate & 1.4 & 0.8 & 0.8 & 0.9 & 0.9 & 0.3 & 0.8 & 0.7 & 0.3 & 0.45 & 0.13 & 0.14 & 0.11 & 0.25 \\
\hline Caproate & 0.3 & -0.6 & -0.4 & -1.0 & -1.4 & -1.2 & -1.2 & -1.5 & 0.4 & 0.69 & 0.23 & 0.38 & 0.73 & 0.19 \\
\hline
\end{tabular}

${ }^{1}$ Treatments (Trt) were continuous abomasal infusion of water (CTRL) or Na-caseinate (CAS) from 1 to 29 DIM; casein protein infusion averaged $696 \pm 1,490 \pm 9$, and $212 \pm$ $10 \mathrm{~g} / \mathrm{d}$ at 4,15 , and 29 DIM, respectively.

${ }^{2} \mathrm{n}=4$.

${ }^{3}$ Fixed effects when prepartum observations are excluded from data set.

${ }^{4}$ Fisher's LSD test for treatment effect on difference between prepartum and 4 DIM.

${ }^{5}$ Fisher's LSD test for prepartum to differ from 4 DIM.

${ }^{* *} P \leq 0.01, * P \leq 0.05, \dagger P \leq 0.10$ : symbols signify difference between LSM within DIM and rows. 
Table 6. Mammary blood plasma flow and metabolite net fluxes $(\mathrm{mmol} / \mathrm{h})^{1}$

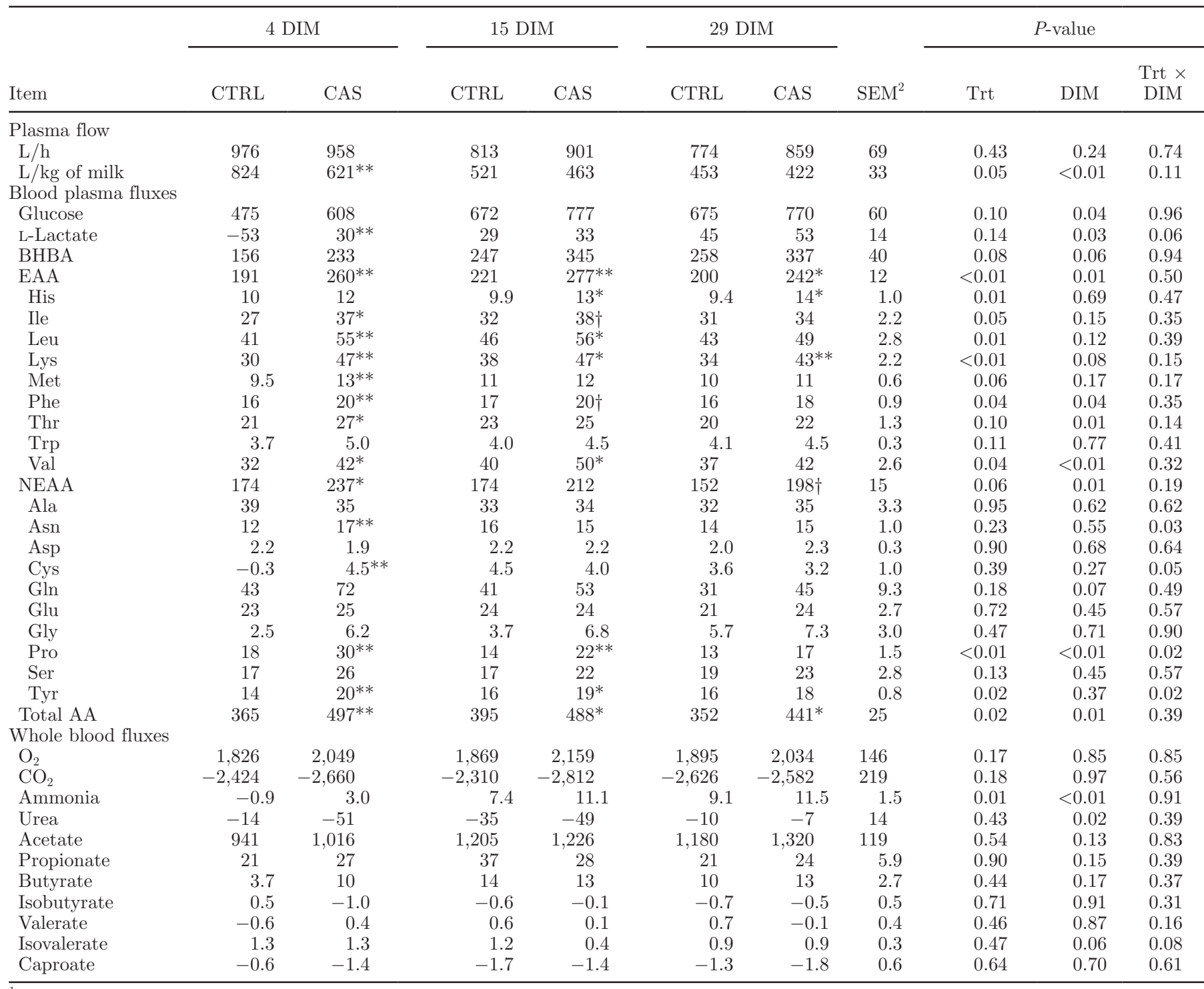

${ }^{1}$ Treatments (Trt) were continuous abomasal infusion of water (CTRL) or Na-caseinate (CAS) from 1 to 29 DIM; casein protein infusion averaged $696 \pm 1,490 \pm 9$, and $212 \pm 10 \mathrm{~g} / \mathrm{d}$ at 4, 15, and $29 \mathrm{DIM}$, respectively.

${ }^{2} \mathrm{n}=4$.

${ }^{* *} P \leq 0.01,{ }^{*} P \leq 0.05, \dagger P \leq 0.10$ : symbols signify difference between LSM within DIM and rows.

from unity at 4 DIM with CTRL, but from above unity for CAS. For Ile, Leu, and Val, the U:O ratios were greater than unity at all times and increased with progressing lactation for Val $(P<0.01)$ but did not change for Ile and Leu $(P \geq 0.22)$.

\section{DISCUSSION}

The overall hypothesis of the present study was that the postpartum protein deficiency limits animal performance. The major outcome of increasing the postpartum protein supply was that more nutrients than the extra AA were partitioned to the mammary gland for milk synthesis. Thus, even though the extra MP supply decreased with DIM for CAS, the treatment resulted in an increased milk production of $7.2 \pm 1.3 \mathrm{~kg} / \mathrm{d}$ and lactose yield of $436 \pm 81 \mathrm{~g} / \mathrm{d}$, on average, during the first 4 wk of lactation, whereas the milk protein yield response to CAS decreased from 451 to $128 \pm 95 \mathrm{~g} / \mathrm{d}$ between 4 and 29 DIM.

\section{Performance}

Milk Production. The response observed in the current study was much greater than the 1 to 4 extra kilograms of milk observed with casein infusion in the 
Table 7. Mammary uptake to output ratio of glucose equivalents and $\mathrm{AA}^{1}$

\begin{tabular}{|c|c|c|c|c|c|c|c|c|c|c|}
\hline Item & \multicolumn{2}{|c|}{$4 \mathrm{DIM}$} & \multicolumn{2}{|c|}{15 DIM } & \multicolumn{2}{|c|}{29 DIM } & $\mathrm{SEM}^{2}$ & \multicolumn{3}{|c|}{$P$-value } \\
\hline EAA & 1.08 & 1.13 & 1.16 & $1.26^{* *}$ & 1.09 & $1.21^{* *}$ & 0.02 & $<0.01$ & $<0.01$ & 0.35 \\
\hline Group $1 \mathrm{EAA}^{3}$ & $1.02^{\mathrm{u}}$ & $1.00^{\mathrm{u}}$ & $1.00^{\mathrm{u}}$ & 1.05 & $0.98^{\mathrm{u}}$ & $1.06^{* *}$ & 0.02 & 0.03 & 0.58 & 0.13 \\
\hline Group $2 \mathrm{EAA}^{4}$ & $1.10^{\mathrm{u}}$ & 1.17 & 1.22 & 1.29 & 1.17 & 1.23 & 0.04 & 0.10 & 0.04 & 0.99 \\
\hline Leu & $1.06^{\mathrm{u}}$ & 1.11 & 1.12 & 1.18 & 1.08 & 1.12 & 0.04 & 0.17 & 0.27 & 0.97 \\
\hline Lys & $1.06^{\mathrm{u}}$ & $1.24^{*}$ & 1.22 & 1.29 & 1.13 & $1.30^{* *}$ & 0.04 & 0.01 & 0.14 & 0.39 \\
\hline Met & $0.96^{\mathrm{u}}$ & $0.98^{\mathrm{u}}$ & $1.00^{\mathrm{u}}$ & $0.96^{\mathrm{u}}$ & $0.98^{\mathrm{u}}$ & $0.96^{\mathrm{u}}$ & 0.03 & 0.72 & 0.93 & 0.74 \\
\hline Thr & 1.11 & 1.10 & 1.14 & $1.05^{\mathrm{u}}$ & $1.02^{\mathrm{u}}$ & $1.05^{\mathrm{u}}$ & 0.03 & 0.37 & 0.14 & 0.33 \\
\hline Trp & $1.04^{\mathrm{u}}$ & $1.04^{\mathrm{u}}$ & $0.99^{\mathrm{u}}$ & $0.97^{\mathrm{u}}$ & $1.07^{\mathrm{u}}$ & $1.05^{\mathrm{u}}$ & 0.06 & 0.71 & 0.59 & 0.99 \\
\hline Val & $1.12^{\mathrm{u}}$ & 1.12 & 1.29 & 1.38 & 1.25 & 1.27 & 0.05 & 0.39 & $<0.01$ & 0.61 \\
\hline NEAA & 0.77 & 0.78 & 0.69 & 0.73 & 0.63 & 0.75 & 0.03 & 0.14 & 0.15 & 0.33 \\
\hline Glu & 0.56 & 0.44 & 0.53 & 0.45 & 0.47 & 0.48 & 0.06 & 0.46 & 0.89 & 0.30 \\
\hline Gly & 0.21 & 0.38 & 0.26 & 0.40 & 0.44 & 0.50 & 0.19 & 0.62 & 0.53 & 0.94 \\
\hline Pro & 0.40 & $0.51^{* *}$ & 0.28 & $0.40^{* *}$ & 0.28 & 0.33 & 0.02 & 0.01 & $<0.01$ & 0.10 \\
\hline Ser & 0.53 & 0.65 & 0.51 & 0.56 & 0.59 & 0.64 & 0.07 & 0.40 & 0.19 & 0.86 \\
\hline Total AA & 0.91 & 0.94 & 0.90 & $0.96 \dagger^{\mathrm{u}}$ & 0.83 & $0.95^{* *}$ & 0.02 & 0.01 & 0.26 & 0.27 \\
\hline
\end{tabular}

${ }^{1}$ Treatments (Trt) were continuous abomasal infusion of water (CTRL) or Na-caseinate (CAS) from 1 to 29 DIM; casein protein infusion averaged $696 \pm 1,490 \pm 9$, and $212 \pm 10 \mathrm{~g} / \mathrm{d}$ at 4, 15, and $29 \mathrm{DIM}$, respectively.

${ }^{2} \mathrm{n}=4$.

${ }^{3}$ Comprising the EAA His, Met, Phe (+Tyr), and Trp.

${ }^{4}$ Comprising the EAA Ile, Leu, Lys, and Val.

${ }^{* *} P \leq 0.01, * P \leq 0.05, \dagger P \leq 0.10$ : symbols signify difference between LSM within DIM and rows.

${ }^{u} P \geq 0.10$ : symbol signifies uptake-to-output ratios not different from 1.00 .

galactopoietic period (Cant et al., 1993; Mackle et al., 2000; Raggio et al., 2006). It was also interesting to note that the greater milk yield obtained with CAS persisted through the entire 4-wk period investigated (Figure 1c), even though the casein protein infusion had been reduced to $272 \pm 17 \mathrm{~g} / \mathrm{d}$ on average during the fourth week of lactation and total MP supply did not differ. Sørensen et al. (2006) observed increased apoptosis of mammary alveolar cells in the early postpartum period, and those authors hypothesized that this could reflect removal of nonfunctional and excess cell capacity. Based on the current work, it could be speculated that the observed persistency in milk synthesis may be caused by reduced postpartum apoptosis due to the greater postpartum protein supply providing more nutrients for mammary cell function. This may indicate that a higher set point for milk synthesis in the mammary gland had been achieved: this possible long-term effect of increasing the postpartum protein supply is intriguing and certainly warrants further investigation.

Milk production responses similar to the present have also been difficult to achieve when increasing the postpartum protein supply with feedstuffs. The obtained early postpartum responses have ranged from $-2 \mathrm{~kg} / \mathrm{d}$ (Komaragiri and Erdman, 1997), no effect (Palmquist and Weiss, 1994; Socha et al., 2005), to 2 to $6 \mathrm{~kg} / \mathrm{d}$ (Garcia-Bojalil et al., 1998; Xu et al., 1998; McCormick et al., 1999). The variation in effects observed on milk production may be related to several factors: (1) protein additions were relatively limited compared with the current study; (2) variations in ruminal degradability of used protein sources; (3) the rates of increment in extra protein supply were relatively slow due to use of TMR and therefore limited by DMI, as compared with the abomasal infusion used in the current study; (4) low palatability of protein sources used; and (5) the forage type used.

In comparison with the current response to increasing the postpartum protein supply, small production responses have been obtained when varying the dietary energy content of the postpartum diets (Rabelo et al., 2003; Guo et al., 2007; Larsen and Kristensen, 2010), and even profound negative effects have even been observed with abomasal glucose infusion (Larsen and Kristensen, 2009b). This indicates the existence of a window of opportunity in the very first days after par- 
turition for inducing both positive and negative effects on the metabolic adaptation to lactation.

Protein and Energy Balances. The marginal utilization of the additional MP supply for milk protein was $60 \%$ at 4 DIM in the current study, considerably greater than the average of $21 \%$ (range 0 to $40 \%$ ) observed with casein infusion during galactopoiesis when basal protein supply were below, at, or above requirement (Hanigan et al., 1998). In spite of the high marginal utilization of the additional MP, the postpartum whole body protein deficiency seemed to be alleviated, as the total MP utilization was greater than $100 \%$ with CAS at 4 DIM $(<100 \%$ indicates mobilization) More EAA were available for all body functions when increasing the postpartum protein supply through increased arterial concentrations. This may benefit the immune system (Li et al., 2007), liver synthesis of export proteins (Connell et al., 1997), and the postpartum proliferation of visceral and liver tissue (Gibb et al., 1992).

The resulting increased need for energetic nutrients to support the greater milk synthesis with CAS was not supported by increased DMI; moreover, the excess total MP supply (not used for milk protein synthesis) theoretically covered a maximum of 30,19 , and $0 \%$ of the glucogenic precursors needed to cover the increased lactose yield at 4, 15, and 29 DIM, respectively. Even so, the greater circulating concentrations of urea indicate that more AA was catabolized for energetic purposes at the same time as more AA was used for milk protein synthesis. Therefore, the cows had to use the dietary nutrient supply more efficiently or mobilize more body depots or both. Increased arterial NEFA concentrations, numerically greater energy deficiency, and greater mammary BHBA uptake with CAS indicate that increased protein supply drove the cows to mobilize more body fat to support the increased energy need for milk production, a situation probably most pronounced during the first week of lactation. Greater mobilization of body fat may become a negative consequence of increasing the postpartum protein supply. Yet a substantial part of the mobilized FA was secreted in milk, as the milk fat yield was $470 \pm 163 \mathrm{~g} / \mathrm{d}$ greater with CAS at 4 DIM compared with CTRL without greater mammary acetate uptake; thus, the greater milk synthesis also provided a route for excretion of mobilized FA via milk fat.

Overall, the current experiment is a proof of the concept that postpartum protein deficiency imposes profound consequences to dairy cows and indicates that it has a greater effect than energy deficiency on performance. Yet, a need for future investigations elucidating how to transfer the effect obtained with abomasal infusion of high quality protein into practical feeding strategies exists.

\section{Mammary Metabolism}

Prepartum. Mammary uptake of nutrients in the prepartum period is generally not well described, and we are not aware of studies measuring blood flows and arterio-venous concentrations differences simultaneously in the prepartum period. Madsen et al. (2008) observed mammary release of BHBA and acetate, whereas mammary uptake of BHBA and acetate was observed in the current study. The difference between the studies may be related to the use of jugular blood as a substitute for arterial blood by Madsen et al. (2008). Investigating salivation using the water extraction method over the head (Storm et al., 2013), substantial uptake of BHBA and lactate, and no uptake of glucose across the head of dairy cows have been observed during rumination (A.C. Storm, Aarhus University, Denmark, personal communication). These observations show that care should be taken when using jugular blood as a substitute for arterial blood. The mammary gland was extracting all AA, except for Gly and Ser, from arterial plasma $14 \mathrm{~d}$ prepartum. To which extent the extracted AA was used for milk synthesis or cell proliferation is unknown; however, even though lactogenesis stage I had initiated, colostrum synthesis would be limited at 2 wk prepartum.

Mammary blood flow in dry cows is likely about half of that during lactation, as interpreted from observations of 2-fold differences at initiation of lactation in dairy cows (Braun et al., 2013) and goats (Davis et al., 1979), as well as at cessation of lactation in goats (Fleet and Peaker, 1978). Prepartum mammary blood and plasma flow in the current study would average 700 and $500 \mathrm{~L} / \mathrm{h}$, respectively, if assuming a 2-fold increment of blood flow in all veins draining the mammary gland from prepartum to 4 DIM. Using these flows, the mammary uptake of metabolites at 2 wk prepartum would average $1,330 \mathrm{mmol} / \mathrm{h}$ of $\mathrm{O}_{2}, 513 \mathrm{mmol} / \mathrm{h}$ of acetate, 93 $\mathrm{mmol} / \mathrm{h}$ of glucose, $28 \mathrm{mmol} / \mathrm{h}$ of EAA, and $17 \mathrm{mmol} / \mathrm{h}$ of nonessential AA. Comparing estimates of prepartum mammary uptake of metabolites other than AA with the measured nutrient uptake at 4 DIM (Table 6) gives increments similar to those obtained in periparturient goats (Davis et al., 1979).

Postpartum AA Uptake. Mammary AA metabolism has typically been studied in the galactopoietic period by gradually changing from undersupply to oversupply of many or specific individual AA. During galactopoiesis, the mammary gland adapts to undersupply by (1) increasing supply by elevating blood flow, (2) increased extraction efficiency of AA from arterial supply, and (3) enhancing intramammary gland utilization toward protein synthesis for the AA taken up in excess of milk protein output (Mepham, 1982; Bequette et al., 
2000). In the current study, mammary metabolism was studied during establishment of lactation (lactogenesis stage I and II through to galactopoiesis), a period characterized by deficiency of protein and energetic nutrients induced by copious milk secretion in lactogenesis stage II.

Though not measured prepartum, the plasma flow would likely have increased greatly at 4 DIM relative to prepartum, as discussed previously. Plasma flow did not differ between treatments in absolute terms $(\mathrm{L} / \mathrm{h})$; hence, a similar number of AA transporters would likely be exposed to nutrients in blood. Yet, more nutrients were absorbed with CAS, thus indicating that neither plasma flow nor capacity of the transporter system, but supply of nutrients was limiting mammary nutrient absorption. Indeed, when expressed relative to milk yield, mammary plasma flow was numerically greater with CTRL in response to the postpartum protein deficiency, but this may simply be a mathematical consequence of the lower milk yield. Further in support of this was that the arterial concentration of metabolites normally considered to participate in regulating mammary blood flow were relatively unaffected by treatment at 4 DIM [e.g., His (Vanhatalo et al., 1999; Bequette et al., 2000; Huhtanen et al., 2002) glucose, BHBA, $\mathrm{O}_{2}$, and acetate (Cant et al., 2003)].

Comparing arterial concentrations prepartum with 4 DIM for CTRL may help to identify the AA that become most deficient with the current diet when lactation was initiated: Leu, Lys, and Tyr decreased the most $(21,23$, and $30 \%$ respectively). Initiation of lactation increased the mammary $\mathrm{A}-\mathrm{V}$ concentration differences for all EAA as observed in goats (Mepham, 1982). The increased postpartum protein supply with CAS induced an even greater increment in mammary A-V concentration differences for Leu, Lys, and Tyr. The mammary A-V concentration differences of Leu, Lys, and Tyr at 4 DIM with CAS were similar to that observed at 29 DIM in the current experiment as well as in later lactation (Guinard and Rulquin, 1994; Lapierre et al., 2009). Altogether, these data would suggest that Lys and Leu would be the 2 limiting EAA in the postpartum period with current feedstuffs.

The greater net mammary uptake of EAA with CAS was roughly in line with the observed increment of milk protein yield; however, nuances in mammary AA metabolism could be observed when subdividing the EAA into group 1 (His, Met, Phe, Tyr, and Trp) or group 2 (Ile, Leu, Lys, and Val) based on mammary U:O ratios close to unity or U:O ratios greater than unity, respectively (Mepham, 1982; Lapierre et al., 2012). The U:O ratio for total group 1 EAA was greater than unity with CAS, but the effect was driven by His, as the other group 1 EAA did not differ from unity. The effect of
CAS on mammary $\mathrm{U}: \mathrm{O}$ ratio for His is discussed later; thus, intramammary metabolism of the group 1 EAA were not affected by the overall postpartum protein deficiency. In contrast, the overall postpartum protein deficiency decreased the intramammary catabolism of the branched-chain AA and Lys, increasing the proportion of their uptake directed toward milk protein secretion. The mammary U:O ratio for Leu was generally in the low end of the studies reviewed by Lapierre et al. (2012), indicating low Leu supply in the current diet, typical of North European diets based on small grain cereals often combined with rapeseed meal. This also agrees with Finnish observations (Vanhatalo et al., 1999; Huhtanen et al., 2002).

The intramammary utilization of Lys was altered by the postpartum Lys deficiency, as indicated by the mammary U:O ratio for Lys at 4 DIM with CTRL not differing from unity, whereas it is usually greater than unity during galactopoiesis (Mepham, 1982; Lapierre et al., 2012). Indeed, Lys-deficient diets have been observed to decrease the mammary $\mathrm{U}: \mathrm{O}$ ratio of Lys (Guinard and Rulquin, 1994; Lapierre et al., 2009), but not to levels as close to unity in the current study. This indicates that at very low supply of Lys combined with a strong driving metabolic demand for milk production, mammary uptake of Lys, on a net basis, is almost totally directed toward milk protein secretion. The reason for mammary U:O ratio not differing from unity for Lys at 4 DIM with CTRL may be related to the process of adaptation to lactation. In the prepartum cow, a net hepatic uptake of Lys has been observed (Larsen and Kristensen, 2013), likely related to catabolism of excess Lys. Likewise, net hepatic uptake of Lys was also observed at 4 DIM (Larsen and Kristensen, 2013), but the net hepatic uptake could not be related to excess Lys supply at this time. Hence, it could be speculated that, with respect to Lys, the process of adaptation to lactation involves both maturation of mammary metabolic pathways, allowing the metabolic flexibility in nonessential EAA synthesis from Lys, demonstrated by Lapierre et al. (2009), and accompanied by downregulation of hepatic Lys uptake.

The postpartum general protein deficiency did not appear to induce His to limit postpartum milk synthesis, as arterial concentrations of His did not decrease between prepartum and 4 DIM in CTRL cows and the mammary A-V concentration difference of His at 4 DIM was not decreased by abomasal casein infusion. The reason for His not appearing as a limiting AA in the postpartum period may be linked to mobilization of carnosine and anserine-bound His in skeletal muscle. Usually, mammary His uptake equals output in milk protein (Lapierre et al., 2012), as observed with CTRL when lactation progresses. The intramammary utiliza- 
tion of His seemed to be altered for His with CAS, as the $\mathrm{U}: \mathrm{O}$ ratio increased from unity at 4 DIM to be greater than unity with the progressing lactation. With casein infusion during galactopoiesis, Raggio et al. (2006) did not observe mammary U:O ratio for His to increase above unity. The reason for the discrepancy is unknown.

\section{Postpartum Uptake of Energetic Metabolites.} It was interesting to note that the mammary gland was releasing lactate on a net basis in the very first days postpartum with CTRL, but not with CAS at 4 DIM or at 15 and 29 DIM with both treatments. This could indicate that the mammary tissue express Cori cycling of glucogenic carbon only prepartum and in the very early postpartum period, as do other peripheral tissues (Kuhla et al., 2011; Larsen and Kristensen, 2013).

Even though the U:O ratio of glucose equivalents was unaffected by casein infusion, the $\mathrm{U}: \mathrm{O}$ ratio of glucose equivalents was closer to unity $(1.10 \pm 0.08)$ when calculated on an incremental basis, indicating that the additional uptake of glucose with CAS was used for lactose synthesis with a relatively high efficiency. The intramammary greater partitioning of glucose to lactose synthesis would imply a greater uptake of other energetic nutrients; which was the case for lactate and BHBA but not for acetate. The present study does not allow calculation of mammary carbon balance, as long-chain FA, triglycerides, and glycerol were not analyzed in plasma or milk. Interestingly, Lemosquet et al. (2009) observed a numerical trend for negative mammary carbon balance when infusing casein as compared with propionate. This indicates that with high AA supply, the mammary gland has a greater dependency of energetic nutrients not typically measured or that the intramammary conversion efficiency of milk synthesis is increased.

\section{CONCLUSIONS}

The current results demonstrate that the postpartum protein deficiency can have substantial negative effect on milk production in dairy cows and indicates that MP supply is of greater importance than energy supply in this respect. In spite of a high utilization of the additional supplied MP for milk synthesis, more EAA were available for synthesis of plasma proteins, immune system, and proliferation of splanchnic tissues. Increasing the MP supply postpartum also seemed to increase the capacity of the mammary gland for milk synthesis as milk and lactose yields were still higher by 29 DIM despite similar MP supply at this time. Yet, future investigations are needed to delineate how to transfer the effect obtained with abomasal infusion into practical feeding strategies.

\section{ACKNOWLEDGMENTS}

We gratefully acknowledge barn staff, Anne Krustrup, Birgit H. Løth, Torkild N. Jakobsen, and Kasper B. Poulsen (Aarhus University, Foulum, Denmark), for their skillful and dedicated technical assistance, care of animals, samplings, and laboratory analyses. Funding for the experiment was provided by The Danish Council for Technology and Innovation (Copenhagen, Denmark; \#10-080821), and the Ministry of Food, Agriculture and Fisheries (Copenhagen, Denmark).

\section{REFERENCES}

Andrew, S. M., D. R. Waldo, and R. A. Erdman. 1994. Direct analysis of body composition of dairy cows at three physiological stages. J. Dairy Sci. 77:3022-3033.

Bell, A. W. 1995. Regulation of organic nutrient metabolism during transition from late pregnancy to early lactation. J. Anim. Sci. 73:2804-2819.

Bell, A. W.. W. S. Burhans, and T. R. Overton. 2000. Protein nutrition in late pregnancy, maternal protein reserves and lactation performance in dairy cows. Proc. Nutr. Soc. 59:119-126.

Bequette, B. J., M. D. Hanigan, A. G. Calder, C. K. Reynolds, G. E. Lobley, and J. C. MacRae. 2000. Amino acid exchange by the mammary gland of lactating goats when histidine limits milk production. J. Dairy Sci. 83:765-775.

Braun, U., E. Forster, U. Bleul, M. Hässig, and C. Schwarzwald. 2013. B-mode and colour Doppler ultrasonography of the milk vein and musculophrenic vein in eight cows during lactation. Res. Vet. Sci. 94:138-143.

Calder, A. G., K. E. Garden, S. E. Anderson, and G. E. Lobley. 1999. Quantitation of blood and plasma amino acids using isotope dilution electron impact gas chromatography/mass spectrometry with $\mathrm{U}-{ }^{13} \mathrm{C}$ amino acids as internal standards. Rapid Commun. Mass Spectrom. 13:2080-2083.

Cant, J. P., R. Berthiaume, H. Lapierre, B. W. McBride, and D. Pacheco. 2003. Responses of the bovine mammary glands to absorptive supply of single amino acids. Can. J. Anim. Sci. 83:341-355.

Cant, J. P., E. J. DePeters, and R. L. Baldwin. 1993. Mammary amino acid utilization in dairy cows fed fat and its relationship to milk protein depression. J. Dairy Sci. 76:762-774.

Chaudhry, A. S., and A. J. F. Webster. 1993. The true digestibility and biological value for rats of undegraded dietary nitrogen in feeds for ruminants. Anim. Feed Sci. Technol. 42:209-221.

Connell, A., A. G. Calder, S. E. Anderson, and G. E. Lobley. 1997. Hepatic protein synthesis in the sheep: Effect of intake as by use of stable-isotope-labelled glycine, leucine and phenylalanine. $\mathrm{Br}$. J. Nutr. 77:255-271.

Dalbach, K. F., M. Larsen, B. M. L. Raun, and N. B. Kristensen. 2011. Effects of supplementation with 2-hydroxy-4-(methylthio)butanoic acid isopropyl ester on splanchnic amino acid metabolism and essential amino acid mobilization in postpartum transition Holstein cows. J. Dairy Sci. 94:3913-3927.

Davis, A. J., I. R. Fleet, J. A. Goode, M. H. Hamon, F. M. M. Walker, and M. Peaker. 1979. Changes in mammary function at the onset of lactation in the goat: Correlation with hormonal changes. J. Physiol. 288:33-44.

Doepel, L., H. Lapierre, and J. J. Kennelly. 2002. Peripartum performance and metabolism of dairy cows in response to prepartum energy and protein intake. J. Dairy Sci. 85:2315-2334.

Fleet, I. R., and M. Peaker. 1978. Mammary function and its control at the cessation of lactation in the goat. J. Physiol. 279:491-507.

Frystyk, J., B. Dinesen, and H. Orskov. 1995. Non-competitive timeresolved immunofluorometric assays for determination of human insulin-like growth factor I and II. Growth Regul. 5:169-176.

Garcia-Bojalil, C. M., C. R. Staples, C. A. Risco, J. D. Savio, and W. W. Thatcher. 1998. Protein degradability and calcium salts of 
long-chain fatty acids in the diets of lactating dairy cows: productive responses. J. Dairy Sci. 81:1374-1384.

Gibb, M. J., W. E. Ivings, M. S. Dhanoa, and J. D. Sutton. 1992. Changes in body components of autumn-calving Holstein-Friesian cows over the first 29 weeks of lactation. Anim. Prod. 55:339-360.

Grummer, R. R. 1995. Impact of changes in organic nutrient metabolism on feeding the transition dairy cow. J. Anim. Sci. 73:28202833.

Guinard, J., and H. Rulquin. 1994. Effects of graded amounts of duodenal infusions of lysine on the mammary uptake of major milk precursors in dairy cows. J. Dairy Sci. 77:3565-3576.

Guo, J., R. R. Peters, and R. A. Kohn. 2007. Effect of a transition diet on production performance and metabolism in periparturient dairy cows. J. Dairy Sci. 90:5247-5258.

Hanigan, M. D., J. P. Cant, D. C. Weakley, and J. L. Beckett. 1998. An evaluation of postabsorptive protein and amino acid metabolism in the lactating dairy cow. J. Dairy Sci. 81:3385-3401.

Huhtanen, P., A. Vanhatalo, and T. Varvikko. 2002. Effects of abomasal infusions of histidine, glucose, and leucine on milk production and plasma metabolites of dairy cows fed grass silage diets. J. Dairy Sci. 85:204-216.

Ingvartsen, K. L., R. J. Dewhurst, and N. C. Friggens. 2003. On the relationship between lactational performance and health: Is it yield or metabolic imbalance that cause production diseases in dairy cattle? A position paper. Livest. Prod. Sci. 83:277-308.

Komaragiri, M. V. S., and R. A. Erdman. 1997. Factors affecting body tissue mobilization in early lactation dairy cows. 1. Effect of dietary protein on mobilization of body fat and protein. J. Dairy Sci. 80:929-937.

Kristensen, N. B. 2000. Quantification of whole blood short-chain fatty acids by gas chromatographic determination of plasma 2-chloroethyl derivatives and correction for dilution space in erythrocytes. Acta Agric. Scand. A Anim. Sci. 50:231-236.

Kristensen, N. B., A. C. Storm, B. M. L. Raun, B. A. Røjen, and D. L. Harmon. 2007. Metabolism of silage alcohols in lactating dairy cows. J. Dairy Sci. 90:1364-1377.

Kuhla, B., G. Nürnberg, D. Albrecht, S. Görs, H. M. Hammon, and C. C. Metges. 2011. Involvement of skeletal muscle protein, glycogen, and fat metabolism in the adaptation on early lactation dairy cows. J. Proteome Res. 10:4252-4262.

Lapierre, H., L. Doepel, E. Milne, and G. E. Lobley. 2009. Responses in mammary and splanchnic metabolism to altered lysine supply in dairy cows. Animal 3:360-371.

Lapierre, H., G. E. Lobley, L. Doepel, G. Raggio, H. Rulquin, and S. Lemosquet. 2012. Triennial lactation symposium: Mammary metabolism of amino acids in dairy cows. J. Anim. Sci. 90:1708-1721.

Larsen, M., and N. B. Kristensen. 2009a. Effect of abomasal glucose infusion on splanchnic amino acid metabolism in periparturient dairy cows. J. Dairy Sci. 92:3306-3318.

Larsen, M., and N. B. Kristensen. 2009b. Effect of abomasal glucose infusion on splanchnic and whole body glucose metabolism in periparturient dairy cows. J. Dairy Sci. 92:1071-1083.

Larsen, M., and N. B. Kristensen. 2010. Effect of a lucerne feeding strategy in the first week postpartum on feed intake and ketone body profiles in blood plasma, urine, and milk in Holstein cows. Acta Agric. Scand. A Anim. Sci. 60:239-249.

Larsen, M., and N. B. Kristensen. 2013. Precursors for liver gluconeogenesis in periparturient dairy cows. Animal 7:1640-1650.

Lemosquet, S., G. Raggio, G. E. Lobley, H. Rulquin, J. Guinard-Flament, and H. Lapierre. 2009. Whole-body glucose metabolism and mammary energetic nutrient metabolism in lactating dairy cows receiving digestive infusions of casein and propionic acid. J. Dairy Sci. 92:6068-6082.

Li, P., Y. L. Yin, D. Li, S. Woo Kim, and G. Wu. 2007. Amino acids and immune function. Br. J. Nutr. 98:237-252.

Loor, J. J. 2010. Genomics of metabolic adaptations in the peripartal cow. Animal 4:1110-1139.
Løvendahl, P., and H. M. Purup. 2002. Technical note: Time-resolved fluoro-immunometric assay for intact insulin in livestock species. J. Anim. Sci. 80:191-195.

Mackle, T. R., D. A. Dwyer, K. L. Ingvartsen, P. Y. Chouinard, D. A. Ross, and D. E. Bauman. 2000. Effects of insulin and postruminal supply of protein on use of amino acids by the mammary gland for milk protein synthesis. J. Dairy Sci. 83:93-105.

Madsen, T. G., M. O. Nielsen, J. B. Andersen, and K. L. Ingvartsen. 2008. Continuous lactation in dairy cows: Effect on milk production and mammary nutrient supply and extraction. J. Dairy Sci. 91:1791-1801.

McCormick, M. E., D. D. French, T. F. Brown, G. J. Cuomo, A. M. Chapa, J. M. Fernandez, J. F. Beatty, and D. C. Blouin. 1999. Crude protein and rumen undegradable protein effects on reproduction and lactation performance of Holstein cows. J. Dairy Sci. 82:2697-2708.

Mepham, T. B. 1982. Amino acid utilization by lactating mammary gland. J. Dairy Sci. 65:287-298.

Myers, W. D., P. A. Ludden, V. Nayigihugu, and B. W. Hess. 2004. Technical note: A procedure for the preparation and quantitative analysis of samples for titanium dioxide. J. Anim. Sci. 82:179-183.

Palmquist, D. L., and W. P. Weiss. 1994. Blood and hydrolyzed feather meals as sources of undegradable protein in high fat diets for cows in early lactation. J. Dairy Sci. 77:1630-1643.

Rabelo, E., R. L. Rezende, S. J. Bertics, and R. R. Grummer. 2003 Effects of transition diets varying in dietary energy density on lactation performance and ruminal parameters of dairy cows. J. Dairy Sci. 86:916-925.

Raggio, G., S. Lemosquet, G. E. Lobley, H. Rulquin, and H. Lapierre. 2006. Effect of casein and propionate supply on mammary protein metabolism in lactating dairy cows. J. Dairy Sci. 89:4340-4351.

Røjen, B. A., P. K. Theil, and N. B. Kristensen. 2011. Effect of nitrogen supply on inter-organ fluxes of urea-N and renal urea-N kinetics in lactating Holstein cows. J. Dairy Sci. 94:2532-2544.

Rutherfurd, S. M., and P. J. Moughan. 1998. The digestible amino acid composition of several milk proteins: Application of a new bioassay. J. Dairy Sci. 81:909-917.

Sjaunja, L. O., L. Bævre, L. Junkkarinen, J. Pedersen, and J. Setälä. 1991. A Nordic proposal for an energy corrected milk (ECM) formula. Pages 156-157 in Proc. 27th Sess. Int. Comm. Rec. Prod. Milk Anim. (ICRPMA). EAAP Publ. No. 50. Eur. Assoc. Anim. Prod. (EAAP), Wageningen, the Netherlands.

Socha, M. T., D. E. Putnam, B. D. Garthwaite, N. L. Whitehouse, N A. Kierstead, C. G. Schwab, G. A. Ducharme, and J. C. Robert 2005. Improving intestinal amino acid supply of pre- and postpartum dairy cows with rumen-protected methionine and lysine. J. Dairy Sci. 88:1113-1126.

Sørensen, M. T., J. V. Nørgaard, P. K. Theil, M. Vestergaard, and K. Sejrsen. 2006. Cell turnover and activity in mammary tissue during lactation and the dry period in dairy cows. J. Dairy Sci. 89:4632-4639.

Storm, A. C., N. B. Kristensen, B. A. Røjen, and M. Larsen. 2013 Technical note: A method for quantification of saliva secretion and salivary flux of metabolites in dairy cows. J. Anim. Sci. 91:57695774

Vanhatalo, A., P. Huhtanen, V. Toivonen, and T. Varvikko. 1999. Response of dairy cows fed grass silage diets to abomasal infusions of histidine alone or in combinations with methionine and lysine. J. Dairy Sci. 82:2674-2685.

Volden, H., ed. 2011. NorFor-The Nordic feed evaluation system. EAAP Publ. No. 130. Wageningen Academic Publishers, Wageningen, the Netherlands.

Xu, S., J. H. Harrison, W. Chalupa, C. J. Sniffen, W. Julien, H. Sato, T. Fujieda, K. Watanabe, T. Ueda, and H. Suzuki. 1998. The effect of ruminal bypass lysine and methionine on milk yield and composition of lactating cows. J. Dairy Sci. 81:1062-1077. 